\title{
Joanna Śmiechowicz Subwencja i dotacje z budżetu państwa - funkcje, zasady przyznawania oraz rola w tworzeniu dochodów jednostek samorządu terytorialnego w Polsce
}

Unconditional and conditional grants from the central budget - functions, transfer rules and role in generating revenues of local and regional government units in Poland

The article focuses on the functions, types, transfer rules and principles of granting of subsidies and specific grants from the state budget to local government units in Poland, however, it also contains international references. The author indicates the key issue related to the use of transfer revenues in financing local government units. Special attention is given to the analysis and assessment of importance and the change in the share of transfer revenues for municipalities, cities with powiat status, powiats and voivodeships for creating their budgetary revenues in 2010-2020. The research was based on data obtained from the database of Statistics Poland.

\begin{tabular}{r|l}
\hline DOI & https://doi.org/10.31268/StudiaBAS.2021.35 \\
\hline Słowa kluczowe & $\begin{array}{l}\text { subwencja, dotacje, dotacje ogólne i dotacje celowe, dochody } \\
\text { transferowe jednostek samorządu terytorialnego, funkcje subwencji } \\
\text { i dotacji }\end{array}$ \\
\hline Keywords & $\begin{array}{l}\text { subsidies, specific grants, unconditional and conditional grants, } \\
\text { transfer revenues of local and regional government units, functions } \\
\text { of subsidies and specific grants }\end{array}$ \\
\hline $\begin{array}{l}\text { doktor nauk ekonomicznych, Uniwersytet Marii Curie-Skłodowskiej } \\
\text { W Lublinie, Katedra Finansów Publicznych } \\
\square \\
\text { ORCID 00000-0003-2101-4068 }\end{array}$ \\
\hline
\end{tabular}

\section{Wprowadzenie}

U podstaw funkcjonowania współczesnych państw demokratycznych leżą zasady decentralizacji i subsydiarności, a podział zadań oraz dochodów publicznych między szczebel rządowy i samorządowy zyskał powszechną akceptację. Jednostki samorządu terytorialnego (JST) odpowiadają za świadczenie usług wymaganych i oczekiwanych przez mieszkańców¹. Zakres zadań wykonywanych przez podmioty tego samego szczebla na obszarze danego państwa jest w zasadzie jednolity, ale potencjał osiągania dochodów we własnym zakresie w każdym przypadku może być inny. Wbudowanie w system dochodów jednostek samorządu terytorialnego transferów w postaci dotacji i subwencji jest rozwiązaniem ogólnie przyjętym, natomiast sposoby podziału dochodów publicznych między szczebel centralny i samorządowy w poszczególnych państwach mocno się różnią.

1 D.A. Carroll, T. Johnson, Examining Small Town Revenues: To What Extent Are They Diversified? „P Public Administration Review" 2010, t. 70, nr 2, s. 223-235, https://doi.org/10.1111/j.1540-6210.2010.02129.x. 
W niektórych państwach głównym źródłem finansowania samorządu terytorialnego są dochody własne, w innych zaś - dochody transferowane z budżetu centralnego jako środki, o których wydatkowaniu decyduje ich beneficjent (subwencje), lub środki o określonym przeznaczeniu (dotacje).

Celem artykułu jest scharakteryzowanie subwencji i dotacji jako źródła dochodów jednostek samorządu terytorialnego, pełnionych przez te środki funkcji, kryteriów ich przyznawania oraz ewolucji ich znaczenia dla tworzenia budżetów gmin, powiatów i województw głównie w Polsce w latach 2010-2020. W treści opracowania odwołano się do rozwiązań w zakresie transferowych źródeł dochodów JST przyjętych w innych państwach. Odwołano się do literatury zarówno krajowej, jak i zagranicznej, przeprowadzono też analizę aktów prawnych obowiązujących w Polsce. W artykule położono duży nacisk na kwestie empiryczne - oparto badania na danych dostępnych w Banku Danych Lokalnych Głównego Urzędu Statystycznego (BDL GUS). Do określenia znaczenia transferów jako dochodów jednostek samorządu terytorialnego oraz jego zmiany w czasie wykorzystano wybrane klasyczne i pozycyjne miary położenia. W analizie dotacji z budżetu państwa uwzględniono te środki, które nie wiążą się z projektami realizowanymi z udziałem środków europejskich.

\section{Pojęcie oraz funkcje dotacji i subwencji}

Dotacje i subwencje są środkami pieniężnymi przekazywanymi konkretnej jednostce samorządu terytorialnego jako jej dochody ${ }^{2}$. Chociaż obie formy pomocy finansowej spełniają podobne funkcje w systemie finansów samorządu terytorialnego, to są one odrębnymi instytucjami prawnymi, które różnią się z jednej strony procedurami uruchamiania, wykorzystywania oraz rozliczania, z drugiej zaś - skutkami prawnymi, m.in. odpowiedzialnością w razie naruszenia tychże procedur ${ }^{3}$.

Subwencje (ang. subsidies, unconditional grants) przekazywane są najczęściej z budżetu centralnego do budżetów JST zgodnie z formułami i regułami, które mają zobiektywizować sposób przekazywania środków i uzależnić ich wysokość od spełnienia przez jednostkę określonych kryteriów. Otrzymane przez samorząd terytorialny kwoty subwencji nie mają z góry określonego celu. Beneficjent subwencji samodzielnie decyduje o sposobie ich wykorzystania ${ }^{4}$. Poza ww. cechami subwencję charakteryzują: ogólność (przyznawana jest na finansowanie zadań własnych), bezzwrotność, nieodpłatność, złożoność struktury, przymusowość oraz to, że stanowi formę dofinansowania każdej jednostki samorządu terytorialnego ${ }^{5}$.

Dotacje (ang. specific grants, conditional grants), w odróżnieniu od subwencji, mają charakter uwarunkowany, a więc albo przekazywane są JST na konkretne cele, albo określono zasady ich

2 T. Uryszek, Dochody transferowe jednostek samorzadu terytorialnego a ich samodzielność wydatkowa „ „Ekonomiczne Problemy Usług" 2011, nr 76, s. 282.

3 Z. Ofiarski, Subwencja jako forma prawna wydatków dokonywanych z budżetu państwa, „Ruch Prawniczy, Ekonomiczny i Społeczny" 2011, z. 3, s. 94.

4 W.E. Oates, An Essay on Fiscal Federalism, „Journal of Economic Literature" 1999, t. 37, nr 3, s. 1126-1127.

5 Szerzej na temat cech subwencji:. Szołno-Koguc, Subwencja ogólna jako instrument wsparcia transferowego samorzadu gminnego, „Prace Naukowe Uniwersytetu Ekonomicznego we Wrocławiu” 2017, nr 485, s. 464, https://doi.org/10.15611/pn.2017.485.37. 
wykorzystania ${ }^{6}$. W zależności od rodzaju dotacji warunki te mogą się różnić, ale konsekwencją niewłaściwego zagospodarowania otrzymanych sum jest konieczność ich zwrotu?

Transferom środków między szczeblami władz publicznych A. Shah przypisuje następujące funkcje:

- rozwiązywanie problemów wynikających z luki fiskalnej powstającej na skutek zbyt niskich dochodów własnych w stosunku do wydatków niezbędnych do wykonania zadań nałożonych na samorząd terytorialny;

- równoważenie sytuacji finansowej poszczególnych jednostek samorządu terytorialnego, tak by wszystkie były w stanie świadczyć usługi na podobnym poziomie przy porównywalnych podatkach lokalnych;

- niwelowanie efektów zewnętrznych, przejawiających się w przysparzaniu korzyści lub ponoszeniu kosztów usług przez podmioty spoza terytorium danej gminy, a więc wpływających na inne jednostki samorządu;

- osiąganie celów istotnych z ogólnopaństwowego punktu widzenia, takich jak zapewnienie jednakowych standardów w oświacie, redukcja bezrobocia, usprawnienie komunikacji itp., przez dofinansowywanie inwestycji infrastrukturalnych ${ }^{8}$.

Wdrożenie mechanizmów pozwalających na realizację pierwszej, drugiej i trzeciej funkcji wynika m.in. z regulacji unijnych, w których przewidziano ochronę finansową słabszych jednostek przez korygowanie skutków nierównego podziału potencjalnych źródeł dochodów i ponoszonych wydatków (Europejska Karta Samorządu Lokalnego, art. 9 ust. 5) oraz przez zharmonizowanie poziomu życia mieszkańców w różnych regionach (Europejska Karta Samorządu Regionalnego, art. 14 ust. 4).

W odniesieniu do subwencji A. Sekuła wskazuje na pięć pełnionych przez nie funkcji:

- wspierającą (wspomaga realizację zadań np. oświatowych, pomocy społecznej, komunalnych usług transportowych),

- wyrównawczą (stanowi podstawę do ustalenia wielkości wyrównania w nawiązaniu do potencjału dochodowego danej jednostki i w odniesieniu do średniej, mediany lub maksymalnej wartości występującej na konkretnym szczeblu JST),

- równoważącą (wiąże się z kosztami realizacji zadań i niejednolitym popytem na dobra i usługi publiczne),

- rekompensacyjną (w Polsce jest realizowana na szczeblu gminnym, a rekompensata odnosi się do utraconych lub zmniejszonych dochodów własnych w wyniku regulacji ustawowych),

- motywacyjną (przejawia się w przyjęciu takiego systemu subwencji, który nie niweluje w pełni dysproporcji dochodowych i stymuluje JST do pozyskiwania dodatkowych źródeł wpływów) ${ }^{9}$.

6 Por.: H.S. Rosen, Public Finance, McGraw-Hill, 2014, s. 513.

7 T. Uryszek, op. cit., s. 283.

8 A. Shah, The Reform of Intergovernmental Fiscal Relations in Developing and Emerging Market Economies, World Bank, Washington 1994, s. 8 i n., https://doi.org/10.1596/0-8213-2836-0.

9 A. Sekuła, System subwencjonowania samorzadu terytorialnego w Polsce i pożadane kierunki racjonalizacji, Politechnika Gdańska, Gdańsk 2016, s. 121-122. 
Do państw europejskich, w których systemy wyrównywania opierają się głównie na kryterium dochodowym, należą: Szwecja, Dania, Włochy, a w mniejszym stopniu - Wielka Brytania, Grecja, Portugalia i Norwegia. Z kolei w Finlandii, Szwajcarii, Hiszpanii, Austrii i Niemczech przy stosowaniu mechanizmów wyrównawczych uwzględnia się głównie koszty wykonania zadań ${ }^{10}$.

W literaturze przedmiotu funkcje dotacji i subwencji nierzadko opisywane są w nawiązaniu do klasycznych funkcji finansów publicznych, realizowanych przez zróżnicowane instrumenty i instytucje finansowe ${ }^{11}$. Zgodnie z takim podejściem wspomnianym transferom z budżetu państwa przypisuje się funkcje: fiskalną, gdyż zapewniają finansowanie zadań; wyrównawczą, realizowaną w drodze redystrybucji pionowej i poziomej; regulacyjną, przejawiającą się w przeciwdziałaniu utrwalaniu się czy pogłębianiu dysproporcji w rozkładzie dochodów własnych JST; stymulacyjną, polegającą na wspieraniu działań zmierzających do poprawy konkurencyjności samorządów ${ }^{12}$. Możliwy jest także inny podział funkcji realizowanych przez dochody transferowe JST. Zgodnie z klasyfikacją K. Owsiak dotacje i subwencje spełniają funkcje: ekonomiczne (np. regulacyjne, zasilające, redystrybucyjne), polityczne (np. stabilizacyjne) i kontrolne ${ }^{13}$. Natomiast B. Guziejewska podkreśla rosnącą wagę funkcji redystrybucyjnej i alokacyjnej ${ }^{14}$.

Przyjęte w poszczególnych państwach rozwiązania prawne określające przesłanki oraz zasady subwencjonowania i dotowania JST znacznie się od siebie różnią, dlatego w literaturze przedmiotu występuje wiele sposobów klasyfikowania tego rodzaju dochodów. Kryteria przyznawania ww. środków przyjęte w systemach dochodów konkretnych państw nakierowane są na osiągnięcie odmiennych celów, dlatego szczegółowe funkcje pełnione przez subwencje, a zwłaszcza dotacje, nie są tożsame. W dalszej części opracowania w przypadku zarówno dotacji, jak i subwencji zostaną uwzględnione zasady przyjęte w polskim porządku prawnym.

\section{Subwencje i dotacje w systemie finansowania samorządu terytorialnego}

Przyjęty w państwach demokratycznych podział zadań i wydatków publicznych pomiędzy szczebel państwowy i samorządowy wymaga repartycji dochodów publicznych w drodze ustawowej ${ }^{15}$, przy czym repartycja ta musi być adekwatna do rozkładu zadań i wiążących się z nimi

10 Ibidem, s. 98.

11 J. Szołno-Koguc, op. cit., s. 465.

12 Por.: L. Patrzałek, Finanse samorządu terytorialnego, Wydawnictwo Uniwersytetu Ekonomicznego we Wrocławiu, Wrocław 2010, s. 202; idem, Subwencja ogólna jako instrument korekcyjno-wyrównawczy w systemie finansów samorzqdu terytorialnego, „Prace Naukowe Uniwersytetu Ekonomicznego we Wrocławiu” 2015, nr 404, s. 244, https://doi.org/10.15611/pn.2015.404.16.

13 K. Owsiak, Kontrowersje wokół dotacji celowych dla jednostek samorzqdu terytorialnego, „Prace Naukowe Uniwersytetu Ekonomicznego we Wrocławiu” 2017, nr 485, s. 341, https://doi.org/10.15611/pn.2017.485.27.

14 B. Guziejewska, Subwencje i dotacje dla samorzadu terytorialnego w polityce finansowej państwa, "Gospodarka Narodowa" 2007, nr 4, s. 75, https://doi.org/10.33119/gn/101396.

15 S. Kańduła, Mechanizmy wyrównywania fiskalnego. Studium empiryczne gmin w Polsce w latach 2004-2014, Wydawnictwo Uniwersytetu Ekonomicznego w Poznaniu, Poznań 2017, s. 34. 
wydatków ${ }^{16}$ (wynika to m.in. z uregulowań Europejskiej Karty Samorządu Lokalnego ${ }^{17}$ ). Aby osiągnąć taki stan, konieczne jest zastosowanie pionowego, a czasem również poziomego podziału dochodów między państwo i samorząd terytorialny. Pierwszy z nich oznacza przyznanie dochodów z podatków, opłat oraz innych dochodów państwu, jednostkom samorządu terytorialnego, a także innym związkom publicznoprawnym, następnie zaś następuje podział tych dochodów między poszczególne szczeble samorządu. Dzięki redystrybucji pionowej JST zyskują dochody własne. Niestety współcześnie najbardziej wydajne fiskalnie daniny przeważnie zasilają budżety państwowe, natomiast samorząd terytorialny, na którym spoczywa obowiązek zaspokajania wielu ważnych potrzeb publicznych, ma przypisane mniej efektywne źródła, co prowadzi do tzw. pionowej (wertykalnej) nierównowagi fiskalnej ${ }^{18}$. Dodatkowo między JST występuje pozioma (horyzontalna) nierównowaga fiskalna pojawiająca się, gdy poszczególne jednostki tego samego szczebla samorządu terytorialnego mają odmienne możliwości gromadzenia dochodów na pokrycie wydatków oraz gdy koszty świadczenia przez nie usług są zróżnicowane ${ }^{19}$. Takie dysproporcje są spowodowane tym, że poszczególne jednostki różnią się od siebie stopniem rozwoju społeczno-gospodarczego, walorami naturalnymi, poziomem uprzemysłowienia czy zamożności mieszkańców. Problemy nieadekwatności i wyrównywania dochodów wynikające z ww. typów nierównowagi fiskalnej poszczególne państwa próbują rozwiązywać z wykorzystaniem systemu subwencji oraz dotacji ${ }^{20}$, jak również przez zapewnienie JST udziału w podatkach państwowych, traktowanych jako odrębny rodzaj dochodów ${ }^{21}$. Za taką kwalifikacją ww. udziałów przemawia to, że JST nie mają samodzielności w kształtowaniu podatków państwowych ani nie ponoszą odpowiedzialności za ich gromadzenie. W Polsce, na podstawie ustawy z dnia 13 listopada 2003 r. o dochodach jednostek samorządu terytorialnego, udziały w podatku dochodowym od osób fizycznych i podatku dochodowym od osób prawnych są zaliczane do dochodów własnych gmin, powiatów i województw. W krajowej literaturze przedmiotu takie rozwiązanie często jest uznawane za niewłaściwe właśnie ze względu na to, że udziały w podatku dochodowym od osób fizycznych i osób prawnych nie spełniają kryteriów dochodów własnych ${ }^{22}$. Przy konstruowaniu systemu wyrównywania dochodów JST w danym kraju można zastosować:

16 A. Borodo, Samorzad terytorialny. System prawnofinansowy, LexisNexis, Warszawa 2004, s. 17.

17 Europejska Karta Samorządu Lokalnego, sporządzona w Strasburgu dnia 15 października 1985 r. (Dz.U. 1994, nr 124, poz. 607; z uwzględnieniem Dz.U. 2006, nr 154, poz. 1107), art. 9.

18 S. Kańduła, Dyskusja na temat zasadności poziomej redystrybucji dochodów między jednostkami samorzadu terytorialnego, "Studia Regionalne i Lokalne" 2015, nr 3(61), s. 104, https://doi.org/10.7366/1509499536106.

19 M. McGovern, A. Kay, G. Bristow, D. Pickernell, Turkeys Don't Vote for Christmas? An Analysis of Horizontal Fiscal Equalisation Experiences in Australia and the United Kingdom, „Economic Papers. Journal of Applied Economics and Policy" 2002, t. 21, nr 4, s. 82, https://doi.org/10.1111/j.1759-3441.2002.tb00330.x.

20 Por.: B. Guziejewska, Zewnętrzne źródła finansowania samorządu terytorialnego, Wydawnictwo Uniwersytetu Łódzkiego, Łódź 2007, s. 28.

21 UN-HABITAT, The Challenge of Local Government Financing in Developing Countries, Nairobi 2015, s. 23, https:// unhabitat.org/ [dostęp: 8 listopada 2021 r.].

22 Por. np.: K. Surówka, M. Winiarz, Kierunki zmian ustawy o dochodach jednostek samorzq̨du terytorialnego, Małopolska Szkoła Administracji Publicznej Uniwersytetu Ekonomicznego w Krakowie, Kraków 2014, s. 26, https:// 
- wyrównywanie pionowe - polegające na uzupełnianiu dochodów środkami publicznymi transferowanymi z budżetu państwa;

- wyrównywanie poziome - polegające na uzupełnianiu dochodów jednostek o niższych dochodach środkami publicznymi pochodzącymi od jednostek tego samego szczebla, ale gromadzących wyższe dochody ${ }^{23}$.

Redystrybucja horyzontalna, tj. między JST, pozwoliła na redukcję dysproporcji w dochodach poszczególnych podmiotów i na dofinansowanie tych o mniejszej zdolności do gromadzenia dochodów bez zwiększania wydatków z budżetów państwowych. Takie rozwiązania zaczęto wdrażać po drugiej wojnie światowej, kiedy z powodu intensywnego wzrostu wydatków publicznych utrwaliła się nierównowaga budżetów centralnych państw europejskich. Cechą redystrybucji horyzontalnej jest selektywność zarówno w zakresie podmiotowym - dotyczy ona wybranych jednostek, jak i przedmiotowym - odnosi się tylko do niektórych dochodów lub wydatków. Transfery poziome są niekiedy nazywane negatywnymi, gdyż dla części jednostek oznaczają zmniejszenie dochodów. Wykorzystanie tego rodzaju mechanizmu wyrównawczego wywołuje kontrowersje wśród badaczy zagadnienia i praktyków. Za dyskusyjne uważa się motywy stosowania transferów horyzontalnych i celowość, skalę oraz instrumenty ich realizacji ${ }^{24}$. Zwolennicy redystrybucji poziomej podkreślają przede wszystkim sprawiedliwość tego rozwiązania. W literaturze określana jest ona nawet „braterską”, podczas gdy redystrybucja pionowa "ojcowską"25. Dodatkowo wskazuje się także na pozytywne efekty w postaci wzrostu efektywności gospodarki lokalnej, zwiększenia środków przeznaczanych na subwencję czy zmniejszenia wydatków budżetu państwa. O wpływie transferów poziomych na efektywność gospodarki lokalnej mówią także ich przeciwnicy, którzy oceniają, że jest on negatywny. Wskazują przy tym na trudności we właściwej alokacji zasobów i zniechęcanie JST do stymulowania wzrostu gospodarczego. Omawiane transfery mogą niekorzystnie oddziaływać zarówno na jednostki dokonujące wpłat, jak i na JST otrzymujące środki. Z tego powodu system redystrybucji poziomej powinien być tak skonstruowany, aby została zachowana równowaga między sprawiedliwością a efektywnością. Oznacza to, że w praktyce wpłaty dokonywane przez zamożniejsze podmioty nie powinny być nadmierne ${ }^{26}$. Warto podkreślić, że systemy oparte wyłącznie na wyrównywaniu poziomym w praktyce nie są spotykane. Znaczenie tego sposobu dofinansowywania JST jest wyraźnie mniejsze niż transferów z budżetu państwa i w różnym stopniu jest on wykorzystywany

www.nist.gov.pl/files/zalacznik/1452372345_K.Sur\%C3\%B3wka\%20-\%20Ustawa\%200\%20dochodach\%20 JST.pdf [dostęp: 10 listopada 2021 r.]; R. Dziemianowicz, Dysfunkcje udziałów w podatkach państwowych w aspekcie zmniejszajqcej się samodzielności dochodowej samorzqdu terytorialnego w Polsce, „Prace Naukowe Uniwersytetu Ekonomicznego we Wrocławiu" 2017, nr 485, s. 9, https://doi.org/10.15611/pn.2017.485.08.

23 A. Sekuła, Stosowanie mechanizmu wyrównania poziomego w województwach - skutki dla dochodów budżetów, „Prace Naukowe Uniwersytetu Ekonomicznego we Wrocławiu” 2018, nr 528, s. 197-198, https://doi. org/10.15611/pn.2018.528.17.

24 S. Kańduła, Mechanizmy..., s. 90.

25 R. Boadway, A. Shah, Fiscal Federalism. Principles and Practice of Multiorder Governance, Cambridge University Press, New York-London 2009, s. 373.

26 S. Kańduła, Mechanizmy..., s. 100. 
w poszczególnych państwach. Zawsze jednak podstawą redystrybucji poziomej są przepisy prawne, a uczestnictwo w niej jest przeważnie obowiązkowe dla JST ${ }^{27}$.

Popularność mechanizmu wyrównywania pionowego wynika m.in. z konieczności świadczenia usług przez samorząd terytorialny spełniających pewne minimalne standardy i zapewnienia obywatelom określonego poziomu życia niezależnie od tego, w jakiej części kraju mieszkają. W państwach europejskich, przykładowo w Wielkiej Brytanii, zakres wyrównywania pionowego jest szeroki. Systemy pionowy i poziomy odgrywają kluczową rolę w finansowaniu samorządu terytorialnego w Danii i Szwecji ${ }^{28}$.

Wykres 1. Udział dotacji i subwencji w dochodach ogółem jednostek samorządu lokalnego w państwach UE w 2017 r. (w \%)

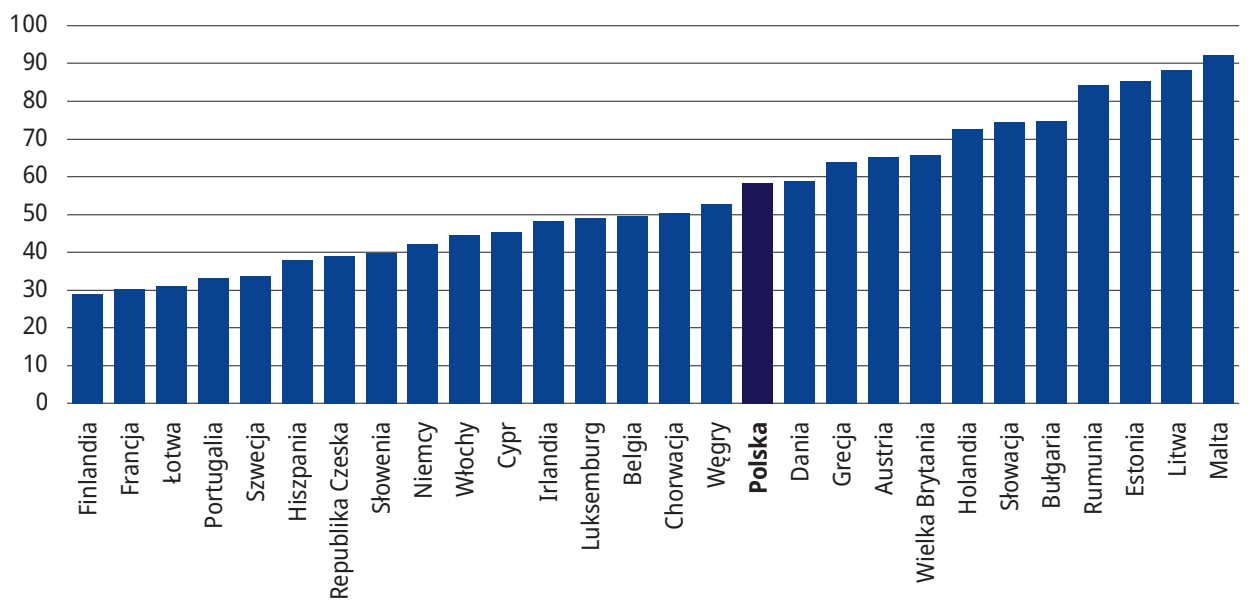

Źródło: opracowanie własne na podstawie: OECD, European Commission, Key Data on Local and Regional Governments in the European Union, 2018, https://www.oecd.org/regional/EU-Local-government-key-data.pdf [dostęp: 20 września 2021 r.].

Jak wynika z danych przedstawionych na wykresie 1, udział dotacji i subwencji w tworzeniu dochodów JST w państwach Unii Europejskiej jest mocno zróżnicowany. Najwyższy poziom (przekraczający 90\%) osiągnęły one w 2017 r. na Malcie, a powyżej 80\% dochodów ogółem stanowiły w trzech państwach, tj. na Litwie, w Estonii i Rumunii. W 13 państwach wspólnoty europejskiej transfery składały się na ponad 50\% dochodów ogółem JST. Stosunkowo niski udział w dochodach JST subwencje ogólne i dotacje celowe miały w Finlandii, we Francji, na Łotwie, w Portugalii i Szwecji, gdzie kształtował się on na poziomie ok. 30\%. Z perspektywy samodzielności wydatkowej JST preferowanym typem transferów są subwencje, ale nie we wszystkich państwach to one przeważają. W Republice Czeskiej i Słowacji środki przekazywane z budżetu

27 S. Kańduła, Dyskusja...

28 P. Swianiewicz, Transfery z budżetu państwa dla samorzq̨ów lokalnych, „Studia Regionalne i Lokalne” 2003, $\operatorname{nr} 1(11)$, s. 109. 
państwa gminom w większości mają wyznaczony cel wydatkowania i stanowią odpowiednio $27 \%$ i $29 \%$ ich dochodów ogółem ${ }^{29}$.

\section{Zasady subwencjonowania i rola transferów ogólnego przeznaczenia w Polsce}

Podstawę prawną aktualnego systemu subwencjonowania JST stanowi ustawa z 2003 r. o dochodach jednostek samorządu terytorialnego ${ }^{30}$. Zgodnie z zawartymi w niej regulacjami subwencja ogólna jest obligatoryjnym dochodem, a więc musi zasilić budżet każdej JST. Powyższa zasada nie jest stosowana w odniesieniu do wszystkich środków składających się na ten rodzaj transferów z budżetu państwa. Ustawodawca zdecydował bowiem, że subwencja nie ma jednolitej budowy, ale składa się z kilku części: wyrównawczej, równoważącej, regionalnej oraz oświatowej. Właśnie ostatni z wymienionych segmentów ustanowiono obowiązkowym dochodem JST. W budżecie państwa tworzy się także rezerwę subwencji ogólnej.

Gminy uprawnione są do otrzymania części wyrównawczej, równoważącej i oświatowej. Pierwsza z nich składa się z kwoty podstawowej przyznawanej na podstawie kryterium dochodowego i kierowana jest do podmiotów, których dochody podatkowe per capita są niższe niż 92\% średnich dochodów podatkowych gmin w kraju, a stopień wyrównania dochodów jest najwyższy w odniesieniu do najuboższych gmin - tj. takich, w których dochody podatkowe na mieszkańca są niższe niż 40\% przeciętnych dochodów tego rodzaju osiąganych przez gminy w państwie. Kwota uzupełniająca przyznawana jest na podstawie kryterium wydatkowego i trafia do gmin charakteryzujących się niższą gęstością zaludnienia niż przeciętnie w państwie, a dochody podatkowe na mieszkańca nie przekraczają 150\% średniej krajowej.

Drugi segment subwencji ogólnej dla gmin, tj. jej część równoważąca, pochodzi z wpłat do budżetu państwa ponoszonych przez gminy uznawane za stosunkowo zamożne, a zatem takie, w których dochody podatkowe na mieszkańca są wyższe niż 150\% przeciętnych dochodów podatkowych gmin w Polsce (z uwzględnieniem opłaty skarbowej i eksploatacyjnej). Wykorzystanie tego mechanizmu oznacza zastosowanie redystrybucji poziomej. Połowa części równoważącej zasila gminy miejskie, reszta - gminy wiejskie i miejsko-wiejskie. Przysługuje ona jednostkom ponoszącym stosunkowo wysokie wydatki na dodatki mieszkaniowe, a w przypadku gmin wiejskich i miejsko-wiejskich - uzyskującym z podatku dochodowego od osób fizycznych oraz podatku rolnego i leśnego wpływy, w przeliczeniu na jednego mieszkańca, niższe niż 80\% średnich dochodów tego rodzaju gmin w państwie ${ }^{31}$.

Niektóre gminy dodatkowo otrzymują subwencję rekompensującą, wypłacaną w celu wyrównania ubytku w dochodach na skutek stosowania zwolnień z podatku od nieruchomości na

29 V. Papcunová, J. Hudáková, M. Štubnová, M. Urbaníková, Revenues of Municipalities as a Tool of Local Self-Government Development (Comparative Study), „Administrative Sciences” 2020, nr 10, s. 10, https://doi. org/10.3390/admsci10040101.

30 Ustawa z dnia 13 listopada 2003 r. o dochodach jednostek samorządu terytorialnego (Dz.U. 2021, poz. 1672) (dalej: u.d.j.s.t.).

31 Art. 21a u.d.j.s.t. 
terenie specjalnych stref ekonomicznych ${ }^{32}$. Podstawę prawną dla subwencji rekompensującej, odmiennie niż subwencji ogólnej, stanowi ustawa o zmianie ustawy o specjalnych strefach ekonomicznych i niektórych ustaw.

Kwotę podstawową subwencji wyrównawczej otrzymują powiaty, których dochody podatkowe per capita są niższe niż przeciętne w powiatach w państwie, a stopień wyrównania sięga $90 \%$, jest więc wysoki. Część uzupełniającą otrzymują jednostki odnotowujące stopę bezrobocia o 10\% wyższą niż przeciętnie powiaty w Polsce. Z kolei część równoważąca dla jednostek tego szczebla przyznawana jest na podstawie pięciu niezależnych od siebie kryteriów, takich jak: długość dróg powiatowych w powiatach, a w miastach na prawach powiatu - dróg wojewódzkich i krajowych (po 30\% środków), wysokość wydatków poniesionych na rodziny zastępcze (9\%), brak urzędu pracy w powiecie i zlecanie zadań przez niego wykonywanych innym powiatom (7\%), zmniejszone wpływy z tytułu subwencji wyrównawczej i równoważącej w stosunku do roku bazowego (24\%). W tym przypadku wpłaty na część równoważącą są ponoszone przez powiaty o dochodach podatkowych wyższych niż 110\% przeciętnych dochodów podatkowych powiatów w państwie.

Do otrzymania kwoty podstawowej subwencji wyrównawczej uprawnione są województwa spełniające kryterium dochodowe, tj. te, w których dochody podatkowe na mieszkańca są niższe niż średnio w województwach w Polsce. Kwota uzupełniająca zasila jednostki zamieszkiwane przez mniej niż 3 mln mieszkańców. Województwa nie otrzymują subwencji równoważącej, lecz regionalną. Obowiązujące obecnie zasady jej przydziału zostały przyjęte na lata 2015-2024. Podział środków, których źródło stanowią wpłaty ponoszone przez województwa o dochodach podatkowych przekraczających 125\% średnich dochodów podatkowych województw w państwie, dokonywany jest między jednostkami, w których dochody podatkowe powiększone o część wyrównawczą subwencji ogólnej per capita są niższe od 125\% średnich dochodów tego rodzaju województw w kraju. Województwo spełniające ww. wstępny warunek otrzyma subwencję regionalną, jeśli na jego obszarze stopa bezrobocia przekracza 110\% średniej w państwie ${ }^{33}$ (w taki sposób rozdziela się 52\% kwoty części regionalnej) lub jeśli dochody podatkowe za rok poprzedzający rok bazowy, powiększone o część wyrównawczą i regionalną subwencji ogólnej, wyliczoną na rok budżetowy w przeliczeniu na jednego mieszkańca, są niższe od 125\% średnich dochodów podatkowych województw na mieszkańca (w taki sposób rozdziela się pozostałe 48\% kwoty części regionalnej).

W odróżnieniu od omówionych powyżej części subwencji ogólnej subwencja oświatowa kierowana jest do wszystkich JST. Jej nazwa nie determinuje kierunku wydatkowania środków, ale podstawą kalkulacji subwencji oświatowej są koszty zadań związanych z edukacją. Od 2000 r. środki przekazywane są zgodnie z koncepcją „pieniądz idzie za uczniem”34. Algorytm podziału

32 Ustawa z dnia 2 października 2003 r. o zmianie ustawy o specjalnych strefach ekonomicznych i niektórych ustaw (Dz.U. nr 188, poz. 1840, ze zm.).

33 Z uwzględnieniem przede wszystkim struktury bezrobocia według wieku.

34 Realizacji koncepcji służy tzw. kalkulacyjny bon oświatowy, określany przez rozdzielenie zaplanowanej na dany rok subwencji oświatowej na przeliczeniową liczbę uczniów, która z kolei ustalana jest z zastosowaniem wag $P$ dla zróżnicowanych zadań szkolnych i pozaszkolnych; por. rozporządzenie Ministra Edukacji i Nauki 
części oświatowej uwzględniający typy i rodzaje szkół oraz placówek prowadzonych przez gminy, powiaty i województwa, liczbę ich uczniów, a także stopnie awansu zawodowego nauczycieli jest ustalany przez ministra właściwego ds. edukacji po zasięgnięciu opinii ministra finansów i reprezentacji samorządu terytorialnego ${ }^{35}$.

Wielkość i udział w dochodach ogółem kwot subwencji ogólnej otrzymywanych przez JST w latach 2010-2020 ulegały zmianom. Przeważnie w gminach, miastach na prawach powiatu oraz powiatach systematycznie się one zwiększały. Niewielkie spadki w stosunku do roku poprzedniego odnotowano tylko w 2014 r. w gminach i powiatach oraz w 2015 r. w powiatach. W województwach samorządowych wysokość subwencji zmieniała się dynamicznie w latach 2015 i 2016 osiągnęła minimalne wartości w okresie objętym badaniem. Redukcja subwencji ogólnej uzyskanej przez województwa w 2015 r. wyniosła ponad 30\%. Było to spowodowane zmianą zasad naliczania części wyrównawczej i regionalnej. Natomiast w latach 2019-2020 wzrost subwencji okazał się w tych jednostkach bardzo dynamiczny - wynosił odpowiednio $17,4 \%$ oraz 25,3\% - i był on głównie efektem otrzymania zwiększonych w stosunku do lat poprzednich kwot części wyrównawczej i regionalnej.

W przypadku każdego szczebla samorządu terytorialnego subwencja ogólna miała inny udział w finansowaniu. Największą rolę jako źródło dochodów, przez cały okres badawczy, odgrywała w powiatach. Maksymalny udział w dochodach subwencja ogólna osiągnęła w 2012 r. i wynosił on prawie 45,4\%, natomiast minimalny - 37,6\% - w 2018 r. Wyraźnie mniejsze znaczenie subwencja ogólna miała w badanym okresie dla gmin. W ich przypadku skrajne wartości wskaźnika odnotowano w 2010 r. - 31,4\% i w 2020 r. - 21,1\%.

W miastach na prawach powiatu znaczenie subwencji ogólnej jako dochodu budżetowego było w latach 2010-2020 bardziej stabilne i znacznie mniejsze niż dla wcześniej omówionych jednostek lokalnych. Udział subwencji ogólnej w dochodach wynosił w ich przypadku od niespełna 22\% w 2010 r. do 18\% w 2018 r. Tak duże zróżnicowanie roli transferów ogólnego przeznaczenia między typami jednostek lokalnych wynikało przede wszystkim z ich potencjału dochodowego. Miasta na prawach powiatu mają znacznie większe możliwości gromadzenia dochodów własnych niż gminy, a zwłaszcza powiaty. Wskaźnik dynamiki łańcuchowy wysokości subwencji ogólnej oraz poszczególnych jej części szczególnie mocno zmienił się w latach 2019 i 2020. Jednostki te otrzymały znacznie więcej środków tytułem części oświatowej (co wiązało się z poszerzeniem zakresu realizowanych zadań oraz z objęciem usługami edukacyjnymi większej liczby uczniów) i tytułem subwencji wyrównawczej (przy czym takie zwiększenie odnotowano już w 2018 r.).

W województwach samorządowych udział subwencji ogólnej w tworzeniu ich dochodów jest znacznie mniejszy niż w gminach oraz powiatach i w badanym okresie wynosił od 21\% w 2010 r. do 11,7\% w 2015 r. Warto podkreślić, że na tym szczeblu udział subwencji ogólnej wykazywał różnokierunkowe (wzrostowe i spadkowe) tendencje i na koniec okresu badawczego był równy $15,3 \%$.

z dnia 18 grudnia 2020 r. w sprawie sposobu podziału części oświatowej subwencji ogólnej dla jednostek samorządu terytorialnego w roku 2021 (Dz.U. 2020, poz. 2384).

35 Art. 28 ust. 6 u.d.j.s.t. 
Tabela 1. Wysokość (w mln zł), dynamika oraz udział subwencji w dochodach gmin w Polsce (w \%) w latach 2010-2020

\section{\begin{tabular}{|l|l|l|l|l|l|l|l|l|l|l|}
2010 & 2011 & 2012 & 2013 & 2014 & 2015 & 2016 & 2017 & 2018 & 2019 & 2020 \\
\hline
\end{tabular}}

Subwencja ogólna w gminach

\begin{tabular}{|l|r|r|r|r|r|r|r|r|r|r|r|}
\hline 1. & 22676 & 23268 & 24649 & 24793 & 24599 & 25419 & 26361 & 27071 & 28359 & 30420 & 31612 \\
\hline 2. & 103,12 & 102,61 & 105,94 & 100,58 & 99,22 & 103,34 & 103,71 & 102,69 & 104,76 & 107,27 & 103,92 \\
\hline 3. & 31,36 & 30,68 & 31,44 & 30,97 & 29,09 & 29,00 & 25,90 & 24,35 & 23,36 & 22,51 & 21,20 \\
\hline
\end{tabular}

Część oświatowa subwencji ogólnej

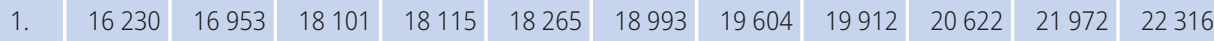

\begin{tabular}{|l|r|r|r|r|r|r|r|r|r|r|r|}
\hline 2. & 104,75 & 104,45 & 106,77 & 100,08 & 100,83 & 103,99 & 103,22 & 101,57 & 103,57 & 106,54 & 101,56 \\
\hline
\end{tabular}

\begin{tabular}{|l|l|l|l|l|l|l|l|l|l|l|l|}
\hline $3^{*}$ & 71,58 & 72,86 & 73,43 & 73,06 & 74,25 & 74,72 & 74,37 & 73,56 & 72,72 & 72,23 & 70,59 \\
\hline
\end{tabular}

Uzupełnienie subwencji ogólnej

\begin{tabular}{|l|r|r|r|r|r|r|r|r|r|r|r|}
\hline 1. & 129 & 129 & 109 & 81 & 52 & 43 & 55 & 80 & 104 & 166 & 207 \\
\hline 2. & 200,00 & 100,17 & 84,43 & 74,10 & 64,35 & 82,53 & 128,20 & 145,72 & 129,42 & 159,51 & 124,85 \\
\hline $3^{*}$ & 0,57 & 0,56 & 0,44 & 0,33 & 0,21 & 0,17 & 0,21 & 0,30 & 0,37 & 0,55 & 0,66 \\
\hline
\end{tabular}

Część wyrównawcza subwencji ogólnej

\begin{tabular}{|l|r|r|r|r|r|r|r|r|r|r|r|}
\hline 1. & 5974 & 5845 & 6078 & 6258 & 5948 & 6042 & 6361 & 6749 & 7306 & 7948 & 8751 \\
\hline 2. & 99,03 & 97,85 & 103,99 & 102,97 & 95,04 & 101,59 & 105,27 & 106,11 & 108,25 & 108,78 & 110,10 \\
\hline $3^{*}$ & 26,34 & 25,12 & 24,66 & 25,24 & 24,18 & 23,77 & 24,13 & 24,93 & 25,76 & 26,13 & 27,68 \\
\hline
\end{tabular}

Część równoważąca subwencji ogólnej

\begin{tabular}{|l|r|r|r|r|r|r|r|r|r|r|r|}
\hline 1. & 336 & 332 & 353 & 332 & 327 & 335 & 337 & 325 & 325 & 334 & 338 \\
\hline 2. & 85,44 & 98,77 & 106,60 & 93,86 & 98,69 & 102,35 & 100,46 & 96,68 & 99,73 & 103,03 & 101,10 \\
\hline $3^{*}$ & 1,48 & 1,42 & 1,43 & 1,34 & 1,33 & 1,32 & 1,28 & 1,20 & 1,14 & 1,10 & 1,07 \\
\hline
\end{tabular}

Część rekompensująca subwencji ogólnej

\begin{tabular}{|l|r|r|r|r|r|r|r|r|r|r|r|r|}
\hline 1. & 7 & 8 & 7 & 7 & 7 & 6 & 5 & 4 & 2 & 0 & 0 \\
\hline 2. & 132,15 & 123,66 & 90,02 & 97,50 & 95,50 & 92,94 & 77,71 & 72,84 & 49,08 & 0,00 & - \\
\hline $3^{*}$ & 0,03 & 0,04 & 0,03 & 0,03 & 0,03 & 0,03 & 0,02 & 0,01 & 0,01 & 0,00 & 0,00 \\
\hline
\end{tabular}

Dochody ogółem

\begin{tabular}{|l|l|l|l|l|l|l|l|l|l|l|l|}
\hline 1. & 72311 & 75831 & 78407 & 80043 & 84549 & 87667 & 101795 & 111189 & 121426 & 135162 & 149090 \\
\hline
\end{tabular}

\begin{tabular}{|l|l|l|l|l|l|l|l|l|l|l|l|}
\hline $\mathbf{2 .}$ & 111,45 & 104,87 & 103,40 & 102,09 & 105,63 & 103,69 & 116,12 & 109,23 & 109,21 & 111,31 & 110,31 \\
\hline
\end{tabular}

1 - wielkość, 2 - dynamika zmian (rok poprzedni = 100\%), 3 - udział w dochodach ogółem, $3^{*}-$ udział w subwencji ogółem

Źródło: opracowanie własne na podstawie danych Banku Danych Lokalnych Głównego Urzędu Statystycznego (BDL GUS), https://bdl.stat.gov.pl [dostęp: 1 września 2021 r.].

Jak wskazują dane zawarte w tabelach 1, 2 i 3, o ważnej roli subwencji jako dochodu budżetowego JST decydują przede wszystkim kwoty przyznawane im jako subwencja oświatowa. Szczególnie wysoki udział ma ona w subwencji ogółem dla miast na prawach powiatu, co jest wynikiem ich zamożności, a w konsekwencji - pozyskiwania stosunkowo niskich kwot tytułem pozostałych części subwencji. Zadania oświatowe należą do najbardziej kosztochłonnych spośród wszystkich 
Tabela 2. Wysokość (w mln zł), dynamika oraz udział subwencji w dochodach miast na prawach powiatu w Polsce (w \%) w latach 2010-2020

\begin{tabular}{|c|c|c|c|c|c|c|c|c|c|c|c|}
\hline & 2010 & 2011 & 2012 & 2013 & 2014 & 2015 & 2016 & 2017 & 2018 & 2019 & 2020 \\
\hline \multicolumn{12}{|c|}{ Subwencja ogólna } \\
\hline 1. & 11804 & 12483 & 13280 & 13547 & 13551 & 13882 & 14481 & 14820 & 15384 & 17118 & 18792 \\
\hline 2. & 104,43 & 105,76 & 106,39 & 102,01 & 100,03 & 102,44 & 104,32 & 102,34 & 103,80 & 111,27 & 109,78 \\
\hline 3. & 21,91 & 21,95 & 21,68 & 21,10 & 19,85 & 19,67 & 19,46 & 18,87 & 17,99 & 18,23 & 18,73 \\
\hline \multicolumn{12}{|c|}{ Część oświatowa subwencji ogólnej } \\
\hline 1. & 10733 & 11475 & 12296 & 12590 & 12628 & 12917 & 13424 & 13750 & 14225 & 15753 & 17280 \\
\hline 2. & 105,30 & 106,91 & 107,15 & 102,40 & 100,30 & 102,29 & 103,92 & 102,43 & 103,45 & 110,74 & 109,69 \\
\hline $3^{*}$. & 90,93 & 91,92 & 92,59 & 92,94 & 93,19 & 93,05 & 92,70 & 92,78 & 92,47 & 92,03 & 91,95 \\
\hline \multicolumn{12}{|c|}{ Uzupełnienie subwencji ogólnej } \\
\hline 1. & 221 & 221 & 277 & 268 & 219 & 236 & 220 & 192 & 174 & 256 & 243 \\
\hline 2. & 80,85 & 100,18 & 125,18 & 96,49 & 81,80 & 107,92 & 93,27 & 87,09 & 90,80 & 146,73 & 94,90 \\
\hline $3^{*}$. & 1,87 & 1,77 & 2,09 & 1,97 & 1,61 & 1,70 & 1,52 & 1,29 & 1,13 & 1,49 & 1,29 \\
\hline \multicolumn{12}{|c|}{ Część wyrównawcza subwencji ogólnej } \\
\hline 1. & 124 & 141 & 143 & 94 & 120 & 129 & 167 & 157 & 217 & 268 & 302 \\
\hline 2. & & 113,45 & 101,31 & 65,80 & 128,45 & 107,06 & 129,15 & 94,34 & 138,20 & 123,58 & 112,37 \\
\hline $3^{*}$ & 1,05 & 1,13 & 1,07 & 0,69 & 0,89 & 0,93 & 1,15 & 1,06 & 1,41 & 1,57 & 1,60 \\
\hline \multicolumn{12}{|c|}{ Część równoważąca subwencji ogólnej } \\
\hline 1. & 718 & 639 & 558 & 588 & 576 & 592 & 663 & 716 & 767 & 841 & 957 \\
\hline 2. & 138,28 & 88,91 & 87,32 & 105,47 & 98,02 & 102,77 & 111,93 & 108,04 & 107,03 & 109,64 & 113,78 \\
\hline $3^{*}$. & 6,08 & 5,12 & 4,20 & 4,34 & 4,25 & 4,27 & 4,58 & 4,83 & 4,98 & 4,91 & 5,09 \\
\hline \multicolumn{12}{|c|}{ Część rekompensująca subwencji ogólnej } \\
\hline 1. & 7 & 7 & 7 & 7 & 7 & 7 & 7 & 5 & 0 & 0 & 11 \\
\hline 2. & 97,18 & 100,04 & 99,18 & 99,82 & 100,00 & 99,83 & 100,33 & 64,99 & 4,51 & 39,86 & 13211,23 \\
\hline $3^{*}$. & 0,06 & 0,06 & 0,05 & 0,05 & 0,05 & 0,05 & 0,05 & 0,03 & 0,00 & 0,00 & 0,06 \\
\hline \multicolumn{12}{|c|}{ Dochody ogółem } \\
\hline 1. & 53886 & 56860 & 61247 & 64217 & 68260 & 70560 & 74420 & 78530 & 85508 & 93894 & 100314 \\
\hline 2. & 107,07 & 105,52 & 107,72 & 104,85 & 106,30 & 103,37 & 105,47 & 105,52 & 108,89 & 109,81 & 106,84 \\
\hline
\end{tabular}

1 - wielkość, 2 - dynamika zmian (rok poprzedni = 100\%), 3 - udział w dochodach ogółem, $3^{*}$ - udział w subwencji ogółem

Źródło: opracowanie własne na podstawie danych BDL GUS, https://bdl.stat.gov.pl [dostęp: 1 września 2021 r.].

wykonywanych przez samorząd lokalny. W Polsce przyjęto zasadę, że źródłem finansowania zdecydowanej większości z nich są środki przekazywane z budżetu państwa. Takie rozwiązanie pozwala uniknąć znacznych dysproporcji w jakości oraz zakresie usług świadczonych przez różne JST na skutek nierównego rozkładu dochodów własnych. W latach 2010-2020 wielkości przekazywanej subwencji oświatowej przeważnie wykazywały tendencje wzrostowe. Jedynie powiaty odnotowywały niewielką redukcję otrzymywanych kwot w latach 2014, 2015, 2017 oraz w 2018 r. 
Tabela 3. Wysokość (w mln zł), dynamika oraz udział subwencji w dochodach powiatów w Polsce (w \%) w latach 2 010-2 020

\begin{tabular}{|c|c|c|c|c|c|c|c|c|c|c|c|}
\hline & 2010 & 2011 & 2012 & 2013 & 2014 & 2015 & 2016 & 2017 & 2018 & 2019 & 2020 \\
\hline \multicolumn{12}{|c|}{ Subwencja ogółem } \\
\hline 1. & 9750 & 10098 & 10222 & 10278 & 10184 & 10049 & 10229 & 10262 & 10506 & 11646 & 13417 \\
\hline 2. & 105,83 & 103,57 & 101,22 & 100,55 & 99,09 & 98,68 & 101,79 & 100,33 & 102,37 & 110,86 & 115,20 \\
\hline 3. & 43,34 & 42,88 & 45,38 & 44,53 & 42,82 & 42,43 & 42,71 & 40,42 & 37,57 & 37,94 & 38,81 \\
\hline \multicolumn{12}{|c|}{ Część oświatowa subwencji ogólnej } \\
\hline 1. & 7360 & 7758 & 7993 & 8024 & 7888 & 7793 & 7823 & 7643 & 7641 & 8564 & 9919 \\
\hline 2. & 104,34 & 105,41 & 103,03 & 100,40 & 98,31 & 98,80 & 100,38 & 97,70 & 99,97 & 112,09 & 115,81 \\
\hline $3^{*}$. & 75,49 & 76,82 & 78,19 & 78,08 & 77,46 & 77,55 & 76,48 & 74,47 & 72,73 & 73,54 & 73,92 \\
\hline \multicolumn{12}{|c|}{ Uzupełnienie subwencji ogólnej } \\
\hline 1. & 163 & 190 & 138 & 115 & 150 & 104 & 137 & 171 & 230 & 169 & 173 \\
\hline 2. & 142,03 & 116,68 & 72,73 & 83,57 & 130,30 & 68,99 & 131,86 & 124,62 & 134,73 & 73,75 & 101,91 \\
\hline $3^{*}$. & 1,67 & 1,88 & 1,35 & 1,12 & 1,48 & 1,03 & 1,34 & 1,66 & 2,19 & 1,45 & 1,29 \\
\hline \multicolumn{12}{|c|}{ Część wyrównawcza subwencji ogólnej } \\
\hline 1. & 1693 & 1543 & 1467 & 1530 & 1518 & 1548 & 1671 & 1838 & 2006 & 2250 & 2607 \\
\hline 2. & 109,81 & 91,10 & 95,11 & 104,30 & 99,20 & 101,97 & 107,97 & 109,97 & 109,12 & 112,17 & 115,87 \\
\hline $3^{*}$ & 17,37 & 15,28 & 14,35 & 14,89 & 14,91 & 15,40 & 16,34 & 17,91 & 19,09 & 19,32 & 19,43 \\
\hline \multicolumn{12}{|c|}{ Część równoważąca subwencji ogólnej } \\
\hline 1. & 534 & 608 & 624 & 607 & 627 & 604 & 598 & 611 & 630 & 663 & 719 \\
\hline 2. & 106,47 & 113,85 & 102,64 & 97,39 & 103,17 & 96,36 & 99,01 & 102,22 & 103,01 & 105,28 & 108,49 \\
\hline $3^{*}$ & 5,47 & 6,02 & 6,10 & 5,91 & 6,15 & 6,01 & 5,84 & 5,96 & 5,99 & 5,69 & 5,36 \\
\hline \multicolumn{12}{|c|}{ Dochody ogółem } \\
\hline 1. & 22496 & 23552 & 22523 & 23078 & 23783 & 23681 & 23948 & 25389 & 27959 & 30696 & 34569 \\
\hline 2. & 112,01 & 104,69 & 95,63 & 102,46 & 103,06 & 99,57 & 101,13 & 106,01 & 110,13 & 109,79 & 112,62 \\
\hline
\end{tabular}

1 - wielkość, 2 - dynamika zmian (rok poprzedni = 100\%), 3 - udział w dochodach ogółem, $3^{*}$ - udział w subwencji ogółem

Źródło: opracowanie własne na podstawie danych BDL GUS, https://bdl.stat.gov.pl [dostęp:1 września 2021 r.].

Ustawa o dochodach jednostek samorządu terytorialnego zawiera wytyczne co do wysokości subwencji oświatowej rozdysponowywanej corocznie z budżetu państwa. Zgodnie z jej przepisami kwota przekazywana w kolejnym roku nie może być niższa niż w roku bieżącym, chyba że zmieni się zakres zadań oświatowych. Zasadę tę respektowano w latach 2010-2020, a zmiany wysokości części oświatowej czasami były niewielkie, uwzględniały bowiem jedynie wskaźnik inflacji, w niektórych zaś latach przekraczały 10\% (w powiatach w 2020 r. wzrost wyniósł prawie 16\%).

Niewątpliwie na zmiany wysokości środków transferowanych tytułem subwencji oświatowej w gminach i powiatach oraz miastach na prawach powiatu miały wpływ reformy systemu edukacji, w tym ostatnia obejmująca m.in. powstawanie nowych typów szkół (np. branżowych) prowadzonych przez powiaty, likwidację gimnazjów oraz wydłużenie nauki w szkołach podsta- 
wowych do ośmiu lat, ale także zwiększenie dostępności opieki przedszkolnej, rozwój kadry dydaktycznej, a w konsekwencji wzrost wynagrodzeń. Zwiększenie kwot subwencji oświatowej wypłaconych z budżetu państwa w 2020 r. w dużej mierze było spowodowane pandemią COVID-19. W trakcie roku budżetowego JST przyznano dodatkowe kwoty na dofinansowanie zakupu usługi dostępu do internetu, sprzętu i oprogramowania użytecznego w prowadzeniu zajęć z wykorzystaniem metod i technik kształcenia na odległość lub innego sposobu realizacji tych zajęć (tzw. 500+ dla nauczycieli) ${ }^{36}$.

Rola subwencji wyrównawczej w tworzeniu dochodów jednostek samorządu lokalnego jest mocno ograniczona w porównaniu z rolą subwencji oświatowej. Najmniejsze znaczenie ma ona w miastach na prawach powiatu, które są stosunkowo zamożne i relatywnie mała ich liczba jest uprawniona do otrzymywania części podstawowej subwencji wyrównawczej. W konsekwencji w okresie objętym badaniem ten segment transferu ogólnego przeznaczenia stanowił zaledwie 0,7\% w 2013 r., a otrzymana przez omawiane jednostki kwota była niższa w stosunku do poprzedniego roku aż o 34,2\%. Po trzech latach dynamicznego wzrostu wysokości części wyrównawczej osiągnęła ona maksymalny udział w strukturze subwencji ogółem miast na prawach powiatu, tj. 1,6\% w $2020 \mathrm{r}$.

Zupełnie inaczej wygląda sytuacja w jednostkach szczebla podstawowego. W ich przypadku udział subwencji wyrównawczej w subwencji ogółem był najwyższy wśród jednostek lokalnych i w 2020 r. osiągnął maksimum, tj. 27,7\%, a minimum, czyli 23,8\%, w 2015 r. W powiatach wskaźnik ten kształtował się na znacznie niższym poziomie, mieszczącym się w granicach od 14,35\% w 2012 r. do 19,43\% w 2020 r. Warto podkreślić, że podobnie jak miasta na prawach powiatu również gminy i powiaty odnotowały w ostatnich trzech latach istotny wzrost tego typu dochodów (tj. 8-10\% gminy oraz 9-16\% powiaty).

Generalnie subwencja równoważąca nie stanowi dużej części dochodów jednostek samorządu lokalnego. Największe znaczenie w latach 2010-2020 miała ona dla powiatów, w przypadku których zapewniła w 2020 r. 7,5\% dochodów. Bardzo niewielką rolę tego typu transfery odgrywały w finansowaniu gmin i miast na prawach powiatu. Należy pamiętać, że w zasadzie wielkość rozdzielanych na danym szczeblu środków jest ograniczona wysokością wpłat dokonanych przez zobowiązane do tego JST.

Przy omawianiu znaczenia poszczególnych części subwencji ogólnej nie można pominąć środków określanych jako jej uzupełnienie. Pochodzą one z podziału rezerwy subwencji ogólnej i służą dofinansowaniu: inwestycji na drogach publicznych, utrzymania rzecznych przepraw promowych, a także remontów, utrzymania i ochrony dróg krajowych i wojewódzkich w granicach miast na prawach powiatu oraz zarządzania nimi. Największe sumy z tytułu podziału rezerwy subwencji zostały przekazane w badanym okresie miastom na prawach powiatu. W gminach i powiatach uzupełnienie subwencji ogólnej odgrywało marginalną rolę w tworzeniu dochodów budżetowych. Warto zauważyć, że na każdym szczeblu samorządu terytorialnego wysokość części uzupełniającej w poszczególnych latach podlegała dużym i różnokierunkowym zmianom.

36 Rada Ministrów, Sprawozdanie z wykonania budżetu państwa za okres od 1 stycznia do 31 grudnia 2020 r. Omówienie, Warszawa 2021, s. 129, https://www.gov.pl/web/finanse/sprawozdanie-roczne-za-2020-rok [dostęp: 3 września 2021 r.]. 
Tabela 4. Wysokość (w mln zł), dynamika oraz udział subwencji w dochodach województw w Polsce (w \%) w latach 2010-2020

\begin{tabular}{|c|c|c|c|c|c|c|c|c|c|c|c|}
\hline & 2010 & 2011 & 2012 & 2013 & 2014 & 2015 & 2016 & 2017 & 2018 & 2019 & 2020 \\
\hline \multicolumn{12}{|c|}{ Subwencja ogólna } \\
\hline 1. & 2942 & 2499 & 2506 & 2639 & 2870 & 1993 & 1965 & 2127 & 2181 & 2561 & 3209 \\
\hline 2. & 105,37 & 84,95 & 100,29 & 105,30 & 108,74 & 69,45 & 98,59 & 108,24 & 102,56 & 117,41 & 125,30 \\
\hline 3. & 20,86 & 16,59 & 16,45 & 16,37 & 16,17 & 11,65 & 14,55 & 14,40 & 12,87 & 13,66 & 15,31 \\
\hline \multicolumn{12}{|c|}{ Część oświatowa subwencji ogólnej } \\
\hline 1. & 686 & 739 & 772 & 780 & 718 & 674 & 647 & 604 & 587 & 610 & 643 \\
\hline 2. & 104,24 & 107,65 & 104,51 & 100,99 & 92,14 & 93,82 & 95,96 & 93,44 & 97,12 & 103,90 & 105,40 \\
\hline $3^{*}$. & 23,33 & 29,56 & 30,80 & 29,54 & 25,03 & 33,81 & 32,91 & 28,41 & 26,91 & 23,81 & 20,03 \\
\hline \multicolumn{12}{|c|}{ Uzupełnienie subwencji ogólnej } \\
\hline 1. & 26 & 20 & 42 & 33 & 19 & 46 & 27 & 31 & 40 & 49 & 398 \\
\hline 2. & 35,16 & 77,24 & 207,69 & 77,36 & 57,06 & 248,50 & 58,77 & 112,39 & 131,29 & 122,38 & 807,81 \\
\hline $3^{*}$. & 0,90 & 0,81 & 1,69 & 1,24 & 0,65 & 2,33 & 1,39 & 1,44 & 1,84 & 1,92 & 12,39 \\
\hline \multicolumn{12}{|c|}{ Część wyrównawcza subwencji ogólnej } \\
\hline 1. & 1274 & 1112 & 1005 & 1092 & 1218 & 949 & 973 & 1113 & 1178 & 1393 & 1576 \\
\hline 2. & 109,06 & 87,32 & 90,36 & 108,63 & 111,60 & 77,89 & 102,55 & 114,37 & 105,83 & 118,25 & 113,16 \\
\hline $3^{*}$ & 43,29 & 44,50 & 40,09 & 41,36 & 42,45 & 47,61 & 49,52 & 52,33 & 54,00 & 54,38 & 49,11 \\
\hline \multicolumn{12}{|c|}{ Część regionalna subwencji ogólnej } \\
\hline 1. & 956 & 628 & 687 & 735 & 915 & 324 & 318 & 379 & 376 & 509 & 593 \\
\hline 2. & 107,26 & 65,70 & 109,44 & 107,01 & 124,40 & 35,41 & 98,14 & 119,24 & 99,30 & 135,34 & 116,34 \\
\hline $3^{*}$ & 32,49 & 25,13 & 27,42 & 27,86 & 31,87 & 16,25 & 16,18 & 17,82 & 17,25 & 19,89 & 18,47 \\
\hline \multicolumn{12}{|c|}{ Ogółem dochody } \\
\hline 1. & 14104 & 15067 & 15236 & 16121 & 17746 & 17110 & 13506 & 14771 & 16954 & 18755 & 20957 \\
\hline 2. & 72,15 & 106,83 & 101,12 & 105,81 & 110,08 & 96,42 & 78,93 & 109,37 & 114,77 & 110,62 & 111,74 \\
\hline
\end{tabular}

1 - wielkość, 2 - dynamika zmian (rok poprzedni = 100\%), 3 - udział w dochodach ogółem, $3^{*}$ - udział w subwencji ogółem

Źródło: opracowanie własne na podstawie danych BDL GUS, https://bdl.stat.gov.pl [dostęp: 1 stycznia 2021 r.].

W kolejnych latach pojawiały się też nowe tytuły uprawniające do pozyskania tego dodatkowego wsparcia finansowego przez JST, np. doposażanie pracowni szkolnych.

Ostatni rodzaj subwencji, tj. subwencja rekompensująca, przekazywany jest tylko gminom oraz miastom na prawach powiatu. Jej wielkość przez wiele lat, zarówno w gminach, jak i miastach na prawach powiatu, kształtowała się na względnie stałym i niskim poziomie. Drastyczny spadek dochodów z tego tytułu jej beneficjenci odnotowali w 2018 r. O ile w gminach obniżka miała charakter trwały, o tyle w miastach na prawach powiatu w 2020 r. nastąpił bardzo wyraźny wzrost subwencji rekompensującej.

W województwach samorządowych znaczenie poszczególnych części subwencji dla tworzenia dochodów budżetowych jest wyraźnie odmienne niż w przypadku jednostek lokalnych. Pod- 
stawowe znaczenie dla województw ma część wyrównawcza, której udział w subwencji ogółem wynosił od 41\% w 2013 r. do 54,4\% w 2019 r., przez co stanowił w tych latach odpowiednio 6,6\% i 7,4\% dochodów ogółem. Udział części regionalnej w ciągu 11 lat objętych badaniem znacznie się zmniejszył - z 32,5\% w 2010 r. do 16,2\% w 2016 r. Wprawdzie od tego czasu stopniowo ulegał zwiększeniu, ale tendencja nie była stała. Radykalna zmiana roli, jaką część regionalna odgrywała w tworzeniu dochodów województw, wiązała się ze zmianą zasad jej przyznawania. Wąski zakres zadań oświatowych powierzonych województwom sprawia, że stosunkowo niewielki jest udział części oświatowej w subwencji ogółem należnej tym jednostkom. W latach 2010-2020 udział ten wyniósł maksymalnie 34\%, a minimalnie - 20\%. Ostatnim transferem środków do województw w ramach subwencji ogólnej są środki pochodzące z podziału rezerwy. Poza 2020 r. województwa nie otrzymywały wysokich kwot z tego tytułu (maks. 2\% subwencji ogółem dla województw). W 2020 r. zasilone zostały 398 mln zł, co stanowiło aż 12,4\% subwencji ogółem dla województw.

W grupie analizowanych miast na prawach powiatu w 2020 r. przeciętna wartość przyznanej im subwencji ogólnej na mieszkańca wyniosła 1670 złł, a mediana - 1580 zł. Odchylenie standardowe w badanej grupie było równe 339 zł. Najniższą subwencję per capita otrzymało miasto Mysłowice - 1027 zł, a najwyższą - 2700 zł - Zamość. W 27 miastach subwencja ogólna na mieszkańca była wyższa niż średnia arytmetyczna. Subwencję powyżej 2000 zł per capita uzyskało 12 jednostek. W powiatach przypadająca na mieszkańca kwota subwencji wyniosła w 2020 r. 560 zł, a mediana - 555 zł. Najniższą wartość subwencji ogólnej per capita otrzymał powiat bydgoski, tj. 153 zł, a najwyższą - 1422 zł - powiat przysuski. Odchylenie standardowe było równe 185 zł. Subwencja ogólna przypadająca na mieszkańca w poszczególnych województwach była niska - minimalną wartość osiągnęła w Mazowieckiem, tj. 19 zł, a maksymalną, tj. 209 zł, w Podlaskiem. Przeciętna wartość subwencji per capita w województwach była równa 112 zł, a wartość środkowa - 143 zł. Odchylenie standardowe w grupie województw osiągnęło 63 zł. W dziewięciu województwach wartość przypadającej na mieszkańca subwencji kształtowała się powyżej średniej.

\section{Rodzaje dotacji z budżetu państwa w Polsce, zasady ich przyznawania oraz ich znaczenie}

Dotacje uzyskiwane przez JST z budżetu państwa są środkami podlegającymi szczególnym zasadom rozliczania. Przekazywane w celu sfinansowania lub dofinansowania realizacji zadań publicznych stanowią jeden z podstawowych instrumentów interwencji ${ }^{37}$ stosowanych przez szczebel centralny. Interwencja ta może mieć na celu poprawę sytuacji finansowej JST, równocześnie dotyczy też finansowania określonych przez państwo rodzajów działalności gmin, powiatów i województw. W Polsce ustawodawca wyróżnia trzy typy dotacji, tj. celowe, przedmiotowe

37 L. Patrzałek, Dotacje jako transfery z budżetu państwa i budżetu jednostki samorzadu terytorialnego, „Annales Universitatis Mariae Curie-Skłodowska. Sectio H. Oeconomia" 2017, t. 51, nr 6, s. 294, https://doi. org/10.17951/h.2017.51.6.293. 
i podmiotowe ${ }^{38}$. Przez takie ich pogrupowanie wskazuje równocześnie, które z nich powinny dominować. W praktyce dotacje celowe stanowią największą grupę transferów o ustalonym z góry przeznaczeniu ${ }^{39}$.

Dla dotacji celowych otrzymywanych przez JST z budżetu państwa charakterystyczne są: bezzwrotność, nieodpłatność, realizacja interesu publicznego, finansowanie ściśle określonego zadania (celowość) ze względu na potrzebę zabezpieczenia rozwoju dziedzin społecznych i gospodarczych JST, a także obowiązek finansowania i realizacji zadania w sposób wymagany przez podmiot dotujący ${ }^{40}$. Podstawą kalkulacji dotacji celowych są koszty podobnych zadań finansowanych z budżetu państwa, a potencjał dochodowy jednostki nie warunkuje otrzymania dotacji. Jeśli tego typu środki przyznawane są na zadania z zakresu administracji rządowej, to powinny w całości pokryć koszty ich realizacji. Kwota niewydana przez beneficjenta podlega zwrotowi. Wykorzystanie dotacji celowej kontrolowane jest z uwzględnieniem kryteriów celowości, legalności, rzetelności i gospodarności. Podmiot uzyskujący dotację ma pewność jej otrzymania, a przekazane środki są uzupełnieniem jego dochodów własnych ${ }^{41}$. W literaturze przedmiotu wskazuje się na istotne, z punktu widzenia JST, mankamenty dotacji celowych. Jak podkreśla L. Patrzałek, odznaczają się one stosunkowo dużą niestabilnością oraz dowolnością przyznawania i przekazywania uzależnioną od decyzji dysponentów części budżetowych. Można więc stwierdzić, że dotacje celowe nie mają cechy powszechności. Wprost przeciwnie - przekazywane są uznaniowo, co może wpłynąć na wielkość przyznawanego podmiotom aplikującym wsparcia czy na wybór preferowanego beneficjenta ${ }^{42}$.

W art. 8 ust. 1 i 2 ustawy o dochodach jednostek samorządu terytorialnego ustawodawca ściśle określił cele, na jakie jednostkom samorządu terytorialnego mogą być przyznawane dotacje z budżetu państwa. Są to:

- zadania z zakresu administracji rządowej oraz inne zadania zlecone ustawami,

- zadania realizowane przez jednostki samorządu terytorialnego na mocy porozumień zawartych z organami administracji rządowej,

- usuwanie bezpośrednich zagrożeń dla bezpieczeństwa i porządku publicznego, skutków powodzi i osuwisk ziemnych oraz skutków innych klęsk żywiołowych,

38 Dotacje przedmiotowe przeznaczane są na kompensatę kosztów świadczenia ustawowo określonej usługi publicznej lub kosztów wytwarzania określonych w ustawie wyrobów. Dotacja tego rodzaju może być udzielona wówczas, gdy wpływy ze sprzedaży usługi nie pokrywają kosztów jej świadczenia lub gdy jest ona nieodpłatna. Dotacje podmiotowe przekazywane są podmiotowi wskazanemu w odrębnej ustawie lub w umowie międzynarodowej wyłącznie na dofinansowanie działalności bieżącej w zakresie określonym w odrębnej ustawie albo umowie międzynarodowej. Przeważnie są przyznawane na działalność kulturalną lub oświatową; por. W. Lachiewicz, System prawa dotacyjnego [w:] Dotacje z budżetów jednostek samorządu terytorialnego, red. W. Lachiewicz, A. Talik, C.H. Beck, Warszawa 2017.

39 K. Owsiak, Kontrowersje wokół dotacji celowych dla jednostek samorzqdu terytorialnego, „Prace Naukowe Uniwersytetu Ekonomicznego we Wrocławiu" 2017, nr 485, s. 342, https://doi.org/10.15611/pn.2017.485.27.

40 Ibidem, s. 344.

41 Miszczuk A., Miszczuk M., Żuk K., Gospodarka samorzq̨du terytorialnego, Wydawnictwo Naukowe PWN, Warszawa 2007, s. 86.

42 K. Owsiak, op. cit., s. 344. 
- finansowanie lub dofinansowanie zadań własnych,

- realizacja zadań wynikających z umów międzynarodowych,

- realizacja zadań inspekcji i straży, o których mowa w ustawie o samorządzie powiatowym. Dodatkowo możliwość dotowania zadań własnych została ograniczona do określonych ustawowo zadań: oświatowych, objętych kontraktem wojewódzkim lub mecenatem państwa w dziedzinie kultury, niektórych zadań w dziedzinie sportu, a także inwestycji i remontów dróg lokalnych. Niekiedy wyrażany jest pogląd, że w praktyce większość przekazywanych samorządowi terytorialnemu na zadania własne dotacji tylko pozornie służy dofinansowaniu ich wykonania z budżetu państwa. Są one przyznawane na przykład na inwestycje szkolne, na działalność instytucji kultury, na rozbudowę dróg, a więc na zadania, na których realizację nie zapewniono samorządom wystarczających środków finansowych, gdy przeprowadzano decentralizację ${ }^{43}$.

Otrzymywane przez gminy dotacje na zadania zlecone przeznaczane są przede wszystkim na finansowanie świadczeń wychowawczych i zadań pomocy społecznej (m.in. finansowanie rządowego programu Rodzina 500+, świadczeń rodzinnych, zasiłków, opłacenie usług opiekuńczych). Powiaty pokrywają tego rodzaju środkami głównie wydatki na utrzymanie powiatowych komend straży pożarnej i na ochronę zdrowia. Województwa natomiast uzyskują dotacje głównie na zadania zlecone z dziedziny transportu i łączności, na wsparcie rodzin i pomoc społeczną oraz rolnictwo (np. na budowę i utrzymanie urządzeń melioracyjnych oraz usuwanie skutków klęsk żywiołowych).

Dotacje celowe uzyskiwane przez JST pełnią zarówno funkcję redystrybucyjną (m.in. transfery na rzecz osób fizycznych), jak i alokacyjną (finansowanie inwestycji). Przyznaje się je podmiotom, które są obciążone określonymi kosztami występującymi na skutek wprowadzonych rozwiązań prawnych, zlecania zadań przez administrację rządową, przyjmowania zadań w drodze porozumienia czy ponoszenia wydatków na preferowane przez państwo zadania własne.

Spośród wszystkich szczebli samorządu terytorialnego gminy uzyskują największe kwoty tytułem dotacji celowych. Ich wysokość gwałtownie wzrosła w 2016 r. w efekcie wdrożenia programu Rodzina 500+, gdyż gminy w ramach zadań zleconych rozdysponowują przyznane rodzinom środki. Analogiczna tendencja wystąpiła w miastach na prawach powiatu. W 2020 r. dotacje przetransferowane w ramach ww. programu stanowiły $44,4 \%$ ogółu dotacji celowych z budżetu państwa dla JST i 63,9\% ogółu dotacji na zadania z zakresu administracji rządowej ${ }^{44}$. Największy udział w dochodach dotacje celowe z budżetu państwa wykazywały na szczeblu gminnym. W latach objętych badaniem udział wzrósł z 15,13\% w 2012 r. do 30\% w 2020 r. W miastach na prawach powiatu również odnotowano wzrost tego wskaźnika z minimalnego poziomu 8,1\% w 2012 r. do 20\% w 2020 r. Przeciwne tendencje, jeśli chodzi o udział tego rodzaju dotacji celowych w dochodach JST, odnotowano w powiatach i województwach. W przypadku powiatów w 2011 r. dotacje celowe z budżetu państwa stanowiły 18,7\%, a w 2020 r. - już tylko $12,6 \%$. W województwach samorządowych zmiana była jeszcze bardziej odczuwalna, gdyż spadek wynosił aż 9,3 p.p. - do zaledwie 3,3\% w 2020 r.

43 E. Malinowska-Misiąg, W. Misiąg, Finanse publiczne w Polsce, LexisNexis, Warszawa 2007, s. 592-593.

44 Rada Ministrów, Sprawozdania z wykonania budżetu państwa za okres od 1 stycznia do 31 grudnia 2020 r. Informacja o wykonaniu budżetów jednostek samorzq̨du terytorialnego, Warszawa 2021, s. 167. 
Tabela 5. Wysokość (w mln zł), dynamika oraz udział dotacji celowych z budżetu państwa w dochodach gmin w Polsce (w \%) w latach 2010-2020

\begin{tabular}{|c|c|c|c|c|c|c|c|c|c|c|c|}
\hline & 2010 & 2011 & 2012 & 2013 & 2014 & 2015 & 2016 & 2017 & 2018 & 2019 & 2020 \\
\hline \multicolumn{12}{|c|}{ Dotacje celowe ogółem } \\
\hline 1. & 12821 & 12316 & 11867 & 12355 & 13561 & 13982 & 28229 & 32987 & 33719 & 38593 & 44784 \\
\hline 2. & 118,07 & 96,06 & 96,35 & 104,11 & 109,76 & 103,11 & 201,89 & 116,86 & 102,22 & 114,45 & 116,04 \\
\hline 3. & 17,73 & 16,24 & 15,13 & 15,44 & 16,04 & 15,95 & 27,73 & 29,67 & 27,77 & 28,55 & 30,04 \\
\hline \multicolumn{12}{|c|}{ Dotacje celowe na zadania z zakresu administracji rządowej ogółem } \\
\hline 1. & 9340 & 8895 & 8822 & 8739 & 9229 & 9500 & 23890 & 28924 & 29113 & 34716 & 41266 \\
\hline 2. & 117,5 & 95,24 & 99,18 & 99,06 & 105,60 & 102,93 & 251,49 & 121,07 & 100,66 & 119,24 & 118,87 \\
\hline 3. & 12,92 & 11,73 & 11,25 & 10,92 & 10,92 & 10,84 & 23,47 & 26,01 & 23,98 & 25,68 & 27,68 \\
\hline \multicolumn{12}{|c|}{ Dotacje celowe na zadania własne ogółem } \\
\hline 1. & 3417 & 3401 & 3024 & 3595 & 4313 & 4439 & 4308 & 4037 & 4581 & 3848 & 3489 \\
\hline 2. & 121,79 & 99,53 & 88,91 & 118,90 & 119,95 & 102,93 & 97,04 & 93,71 & 113,48 & 84,02 & 90,66 \\
\hline 3. & 4,73 & 4,48 & 3,86 & 4,49 & 5,10 & 5,06 & 4,23 & 3,63 & 3,77 & 2,85 & 2,34 \\
\hline \multicolumn{12}{|c|}{ Dotacje celowe na zadania realizowane na podstawie porozumień z organami administracji rządowej } \\
\hline 1. & 64 & 20 & 21 & 20 & 19 & 44 & 31 & 27 & 25 & 29 & 29 \\
\hline 2. & 60,94 & 30,94 & 104,24 & 98,62 & 95,78 & 225,10 & 71,40 & 86,53 & 94,20 & 113,74 & 100,21 \\
\hline 3. & 0,09 & 0,03 & 0,03 & 0,03 & 0,02 & 0,05 & 0,03 & 0,02 & 0,02 & 0,02 & 0,02 \\
\hline \multicolumn{12}{|c|}{ Dotacje celowe z budżetu państwa inwestycyjne } \\
\hline 1. & 1029 & 1155 & 682 & 604 & 686 & 865 & 721 & 740 & 1245 & 569 & 345 \\
\hline 2. & 115,62 & 112,27 & 59,05 & 88,60 & 113,54 & 126,01 & 83,44 & 102,65 & 168,19 & 45,71 & 60,61 \\
\hline 3. & 8,02 & 9,38 & 5,75 & 4,89 & 5,06 & 6,18 & 2,56 & 2,24 & 3,69 & 1,48 & 0,77 \\
\hline
\end{tabular}

1 - wielkość, 2 - dynamika zmian (rok poprzedni = 100\%), 3 - udział w dochodach ogółem

Źródło: opracowanie własne na podstawie danych BDL GUS, https://bdl.stat.gov.pl [dostęp: 1 stycznia 2021 r.].

Jak zobrazowano na podstawie danych w tabelach 5, 6, 7 i 8, dotacje budżetowe kierowane są do wszystkich szczebli struktury samorządowej na realizację zadań zleconych z zakresu administracji rządowej. Rzadkością natomiast jest, by JST przyjmowały zadanie w drodze porozumienia z organem administracji rządowej, i ta prawidłowość dotyczy wszystkich typów samorządu terytorialnego.

Niezwykle interesująca jest kwestia dofinansowania zadań własnych JST z budżetu państwa. Nie wszystkie szczeble samorządu terytorialnego mogą liczyć na podobny poziom wsparcia. W latach 2010-2020 nominalnie najwięcej środków tego rodzaju przekazano gminom i miastom na prawach powiatu. Najniższe kwoty zasiliły budżety województw. Gdy porówna się udział dotacji celowych na zadania własne w dochodach ogółem, można stwierdzić, że największe znaczenie omawiane transfery miały w przypadku powiatów, najmniejsze - województw. Generalnie wsparcie z budżetu państwa na finansowanie zadań własnych gmin i miast na prawach powiatu od 2016 r. ulega stopniowej redukcji. Natomiast kwoty uzyskiwane przez powiaty i województwa bardzo się różnią w poszczególnych latach i trudno ustalić 
Tabela 6. Wysokość (w mln zł), dynamika oraz udział dotacji celowych z budżetu państwa w dochodach miast na prawach powiatu w Polsce (w \%) w latach 2010-2020

\begin{tabular}{|c|c|c|c|c|c|c|c|c|c|c|c|}
\hline & 2010 & 2011 & 2012 & 2013 & 2014 & 2015 & 2016 & 2017 & 2018 & 2019 & 2020 \\
\hline \multicolumn{12}{|c|}{ Dotacje celowe z budżetu państwa ogółem } \\
\hline 1. & 5072 & 4773 & 4955 & 5497 & 5912 & 6129 & 10886 & 12641 & 12926 & 16382 & 20062 \\
\hline 2. & 111,15 & 94,10 & 103,82 & 110,93 & 107,55 & 103,67 & 177,62 & 116,12 & 102,26 & 126,73 & 122,47 \\
\hline 3. & 9,41 & 8,39 & 8,09 & 8,56 & 8,66 & 8,69 & 14,63 & 16,10 & 15,12 & 17,45 & 20,00 \\
\hline \multicolumn{12}{|c|}{ Dotacje celowe z budżetu państwa na zadania z zakresu administracji rządowej ogółem } \\
\hline 1. & 3580 & 3576 & 3653 & 3762 & 3947 & 4118 & 8997 & 10896 & 11211 & 14659 & 18324 \\
\hline 2. & 106,87 & 99,89 & 102,15 & 102,97 & 104,94 & 104,32 & 218,48 & 121,10 & 102,89 & 130,76 & 125,00 \\
\hline 3. & 6,64 & 6,29 & 5,96 & 5,86 & 5,78 & 5,84 & 12,09 & 13,87 & 13,11 & 15,61 & 18,27 \\
\hline \multicolumn{12}{|c|}{ Dotacje celowe z budżetu państwa na zadania własne ogółem } \\
\hline 1. & 1469 & 1165 & 1292 & 1721 & 1951 & 1993 & 1867 & 1727 & 1689 & 1667 & 1687 \\
\hline 2. & 122,48 & 79,34 & 110,83 & 133,26 & 113,38 & 102,11 & 93,71 & 92,51 & 97,79 & 98,65 & 101,26 \\
\hline 3. & 2,73 & 2,05 & 2,11 & 2,68 & 2,86 & 2,82 & 2,51 & 2,20 & 1,98 & 1,77 & 1,68 \\
\hline \multicolumn{12}{|c|}{$\begin{array}{l}\text { Dotacje celowe z budżetu państwa na zadania realizowane na podstawie porozumień z organami administracji } \\
\text { rządowej ogółem }\end{array}$} \\
\hline 1. & 24 & 32 & 11 & 14 & 13 & 18 & 22 & 18 & 26 & 56 & 51 \\
\hline 2. & 163,00 & 133,94 & 34,37 & 130,74 & 92,14 & 138,34 & 120,37 & 81,64 & 146,11 & 216,96 & 89,76 \\
\hline 3. & 0,04 & 0,06 & 0,02 & 0,02 & 0,02 & 0,03 & 0,03 & 0,02 & 0,03 & 0,06 & 0,05 \\
\hline \multicolumn{12}{|c|}{ Dotacje celowe z budżetu państwa inwestycyjne } \\
\hline 1. & 491 & 219 & 170 & 264 & 210 & 227 & 121 & 95 & 157 & 157 & 140 \\
\hline 2. & 126,84 & 44,60 & 77,63 & 155,29 & 79,55 & 108,10 & 53,30 & 78,51 & 165,26 & 100,00 & 89,17 \\
\hline 3. & 9,68 & 4,59 & 3,43 & 4,81 & 3,56 & 3,70 & 1,11 & 0,75 & 1,22 & 0,96 & 0,70 \\
\hline
\end{tabular}

1 - wielkość, 2 - dynamika zmian (rok poprzedni = 100\%), 3 - udział w dochodach ogółem

Źródło: opracowanie własne na podstawie danych BDL GUS, https://bdl.stat.gov.pl [dostęp: 1 stycznia 2021 r.].

tendencję zmian. W 2020 r. wysokość dotacji celowych przekazanych gminom, powiatom i województwom na zadania własne była niższa niż w roku poprzednim. Generalnie ograniczono transfery na zadania inwestycyjne, natomiast pojawiły się dotacje na zadania własne JST związane z przeciwdziałaniem pandemii COVID-19, np. na przystosowanie szpitali czy ratownictwo medyczne.

Większość dotacji celowych otrzymywanych przez JST z budżetu państwa przyznawana jest na finansowanie wydatków bieżących. Niemniej jednak podmioty te uzyskują także dotacje inwestycyjne z budżetu państwa. Ich wielkość w kolejnych latach była bardzo zróżnicowana. Generalnie na początku okresu objętego analizą dotacje były wyższe w jednostkach wszystkich szczebli. Ich udział w dotacjach ogółem w 2010 r. wynosił w przypadku gmin i miast na prawach powiatu ok. 10\%, w powiatach - powyżej 16\%, a województwach - aż 43\%. Choć w 2020 r. dotacje inwestycyjne z budżetu państwa w dochodach ogółem województw były zdecydowanie wyższe niż w jednostkach z pozostałych szczebli samorządu terytorialnego, to 

Tabela 7. Wielkość (w mln zł), dynamika oraz udział dotacji celowych z budżetu państwa w do-
chodach powiatów w Polsce (w \%) w latach 2010-2020

\begin{tabular}{|c|c|c|c|c|c|c|c|c|c|c|c|}
\hline & 2010 & 2011 & 2012 & 2013 & 2014 & 2015 & 2016 & 2017 & 2018 & 2019 & 2020 \\
\hline \multicolumn{12}{|c|}{ Dotacje celowe z budżetu państwa ogółem } \\
\hline 1. & 4153 & 4401 & 3788 & 4035 & 4149 & 3958 & 3950 & 4067 & 4465 & 4040 & 4346 \\
\hline 2. & 102,67 & 105,96 & 86,07 & 106,53 & 102,82 & 95,40 & 99,80 & 102,97 & 109,77 & 90,48 & 107,58 \\
\hline 3. & 18,46 & 18,69 & 16,82 & 17,48 & 17,44 & 16,71 & 16,49 & 16,02 & 15,97 & 13,16 & 12,57 \\
\hline \multicolumn{12}{|c|}{ Dotacje celowe z budżetu państwa na zadania z zakresu administracji rządowej ogółem } \\
\hline 1. & 2408 & 2481 & 2591 & 2725 & 2843 & 2658 & 2691 & 2743 & 2794 & 2972 & 3378 \\
\hline 2. & 101 & 103 & 104 & 105 & 104 & 93 & 101 & 102 & 102 & 106 & 114 \\
\hline 3. & 10,71 & 10,53 & 11,51 & 11,81 & 11,95 & 11,22 & 11,24 & 10,80 & 9,99 & 9,68 & 9,77 \\
\hline \multicolumn{12}{|c|}{ Dotacje celowe z budżetu państwa na zadania własne ogółem } \\
\hline 1. & 1726 & 1906 & 1186 & 1298 & 1294 & 1292 & 1252 & 1314 & 1647 & 1035 & 925 \\
\hline 2. & 107,56 & 110,44 & 62,19 & 109,50 & 99,70 & 99,79 & 96,95 & 104,93 & 125,39 & 62,82 & 89,36 \\
\hline 3. & 7,67 & 8,09 & 5,26 & 5,63 & 5,44 & 5,45 & 5,23 & 5,17 & 5,89 & 3,37 & 2,68 \\
\hline \multicolumn{12}{|c|}{$\begin{array}{l}\text { Dotacje celowe z budżetu państwa na zadania realizowane na podstawie porozumień z organami administracji } \\
\text { rządowej ogółem }\end{array}$} \\
\hline 1. & 19 & 13 & 10 & 11 & 11 & 9 & 7 & 11 & 23 & 33 & 43 \\
\hline 2. & 102.30 & 71,60 & 78,40 & 106,25 & 101,38 & 76,13 & 76,14 & 165,26 & 212,49 & 142,20 & 132,67 \\
\hline 3. & 0,08 & 0,06 & 0,05 & 0,05 & 0,05 & 0,04 & 0,03 & 0,04 & 0,08 & 0,11 & 0,13 \\
\hline \multicolumn{12}{|c|}{ Dotacje celowe z budżetu państwa inwestycyjne } \\
\hline 1. & 672 & 679 & 322 & 491 & 595 & 675 & 516 & 542 & 829 & 290 & 234 \\
\hline 2. & 100,90 & 101,11 & 47,46 & 152,30 & 121,21 & 113,40 & 76,41 & 105,13 & 152,86 & 35,04 & 80,71 \\
\hline 3. & 16,18 & 15,44 & 8,51 & 12,17 & 14,35 & 17,06 & 13,06 & 13,33 & 18,57 & 7,19 & 5,39 \\
\hline
\end{tabular}

1 - wielkość, 2 - dynamika zmian (rok poprzedni = 100\%), 3 - udział w dochodach ogółem

Źródło: opracowanie własne na podstawie danych BDL GUS, https://bdl.stat.gov.pl [dostęp: 1 stycznia 2021 r.].

wynosiły one zaledwie $11 \%$. W gminach i miastach na prawach powiatu, gdzie zawsze były one niższe, odsetek ten stanowił niespełna 1\%. Poza dotacjami o charakterze inwestycyjnym z budżetu państwa JST otrzymują dotacje na inwestycje współfinansowane środkami europejskimi. Ostatni rodzaj transferów nie został uwzględniony w badaniu. Dotacje przekazywane z budżetu państwa na inwestycje przyznawane są głównie na zadania z zakresu transportu i łączności, w szczególności na drogi, a także oświatę i wychowanie oraz ochronę zdrowia. Należy podkreślić, że wyraźne zmniejszenie dotacji z budżetu państwa na budowę i przebudowę lub remont dróg publicznych było efektem zmiany sposobu wspierania JST w tym zakresie - w 2019 r. środki pochodziły głównie z Funduszu Dróg Samorządowych, a w 2020 r. z Rządowego Funduszu Rozwoju Dróg i Rządowego Funduszu Inwestycji Lokalnych, a nie bezpośrednio z budżetu państwa.

Pandemia COVID-19, która rozpoczęła się w trakcie roku budżetowego, wymusiła korekty niektórych wielkości i tytułów przekazywanych dotacji w 2020 r. Zwiększono m.in. dotacje 
Tabela 8. Wysokość (w mln zł), dynamika oraz udział dotacji celowych z budżetu państwa w dochodach województw w Polsce (w \%) w latach 2010-2020

\begin{tabular}{|c|c|c|c|c|c|c|c|c|c|c|c|}
\hline & 2010 & 2011 & 2012 & 2013 & 2014 & 2015 & 2016 & 2017 & 2018 & 2019 & 2020 \\
\hline \multicolumn{12}{|c|}{ Dotacje celowe z budżetu państwa ogółem } \\
\hline 1. & 1820 & 1866 & 1877 & 1975 & 2188 & 2074 & 1607 & 1551 & 1019 & 1119 & 681 \\
\hline 2. & 102,72 & 102,49 & 100,62 & 105,21 & 110,78 & 94,79 & 77,48 & 96,49 & 65,72 & 109,78 & 60,91 \\
\hline 3. & 12,91 & 12,38 & 12,32 & 12,25 & 12,33 & 12,12 & 11,90 & 10,50 & 6,01 & 5,96 & 3,25 \\
\hline \multicolumn{12}{|c|}{ Dotacje celowe z budżetu państwa na zadania z zakresu administracji rządowej ogółem } \\
\hline 1. & 1500 & 1584 & 1645 & 1635 & 1932 & 1559 & 1318 & 1271 & 710 & 734 & 615 \\
\hline 2. & 107,80 & 105,55 & 103,85 & 99,40 & 118,17 & 80,69 & 84,54 & 96,43 & 55,85 & 103,34 & 83,80 \\
\hline 3. & 10,64 & 10,51 & 10,80 & 10,14 & 10,89 & 9,11 & 9,76 & 8,60 & 4,19 & 3,91 & 2,93 \\
\hline \multicolumn{12}{|c|}{ Dotacje celowe z budżetu państwa na zadania własne ogółem } \\
\hline 1. & 304 & 280 & 232 & 338 & 255 & 514 & 288 & 279 & 309 & 380 & 51 \\
\hline 2. & 98,67 & 92,17 & 82,75 & 146,11 & 75,39 & 201,52 & 56,09 & 96,82 & 110,53 & 123,31 & 13,39 \\
\hline 3. & 2,15 & 1,86 & 1,52 & 2,10 & 1,44 & 3,00 & 2,13 & 1,89 & 1,82 & 2,03 & 0,24 \\
\hline \multicolumn{12}{|c|}{$\begin{array}{l}\text { Dotacje celowe z budżetu państwa na zadania realizowane na podstawie porozumień z organami administracji } \\
\text { rządowej ogółem }\end{array}$} \\
\hline 1. & 16 & 2 & 1 & 2 & 1 & 1 & 1 & 0 & 1 & 5 & 16 \\
\hline 2. & 100,90 & 12,19 & 41,74 & 209,49 & 48,01 & 123,78 & 68,82 & 61,62 & 137,84 & 769,17 & 342,15 \\
\hline 3. & 0,11 & 0,01 & 0,01 & 0,01 & 0,00 & 0,01 & 0,01 & 0,00 & 0,00 & 0,02 & 0,07 \\
\hline \multicolumn{12}{|c|}{ Dotacje celowe z budżetu państwa inwestycyjne } \\
\hline 1. & 789 & 719 & 678 & 674 & 915 & 674 & 303 & 269 & 78 & 105 & 76 \\
\hline 2. & 91,18 & 94,31 & 99,30 & 135,87 & 73,60 & 45,00 & 88,66 & 29,07 & 134,71 & 71,87 & 91,18 \\
\hline 3. & 43,34 & 38,55 & 36,14 & 34,11 & 41,83 & 32,48 & 18,86 & 17,33 & 7,67 & 9,41 & 11,10 \\
\hline
\end{tabular}

1 - wielkość, 2 - dynamika zmian (rok poprzedni = 100\%), 3 - udział w dochodach ogółem

Źródło: opracowanie własne na podstawie danych BDL GUS, https://bdl.stat.gov.pl [dostęp: 1 stycznia 2021 r.].

klasyfikowane w dziale „Ochrona zdrowia” w związku z przekazywaniem środków na finansowanie zadań związanych ze zwalczaniem zakażenia, z zapobieganiem rozprzestrzenianiu się koronawirusa, profilaktyką oraz z walką ze skutkami choroby zakaźnej wywołanej wirusem SARS-CoV-2. Powiaty otrzymały zwiększone dotacje celowe na zadania z zakresu zarządzania kryzysowego, w tym związane z pandemią. $Z$ kolei województwom nie przekazano pełnej kwoty zaplanowanych dotacji w zakresie ulgowych przejazdów środkami transportu autobusowego ze względu na mniejsze zapotrzebowanie dysponentów oraz podjęte w 2020 r. decyzje o blokowaniu wydatków budżetowych.

Podobnie jak w przypadku subwencji ogólnej również dotacje celowe w przeliczeniu na mieszkańca wykazują znaczny stopień zróżnicowania, jeśli chodzi o rodzaje jednostek samorządu terytorialnego i między jednostkami tego samego szczebla. W 2020 r. poziom dotacji celowych z budżetu państwa był najmniejszy w województwach samorządowych i wahał się w granicach 7,80-33 zł, przy czym najniższą wartość odnotowano w województwie śląskim, 
a najwyższą - w lubuskim. Wartość średnia i mediana były do siebie bardzo zbliżone i wynosiły odpowiednio 20,80 zł oraz 20,70 zł, natomiast odchylenie standardowe - 7 zł. Wysokość dotacji, jakie otrzymywały powiaty w przeliczeniu na jednego mieszkańca, była wyższa niż w województwach i mieściła się w przedziale od 31 zł (powiat siedlecki) do 577 zł (powiat węgorzewski). Podobnie jak w województwach również w powiatach wartości średnia i środkowa były do siebie bardzo zbliżone, gdyż wynosiły 178 zł i 188 zł, a odchylenie miało wartość 68 zł. Poziom dotacji uzyskiwanych przez miasta na prawach powiatu był znacznie wyższy niż omówionych wcześniej jednostek. Jego maksymalny poziom na jednego mieszkańca wynosił 2045 zł w Przemyślu, a minimalny - 1353 zł w Katowicach. Również w przypadku tych jednostek różnice między wartością średnią i środkową nie były duże, gdyż wielkości te kształtowały się na poziomie 1683 zł oraz 1668 zł, a odchylenie standardowe równało się 158 zł. Przeciętna wartość dotacji z budżetu państwa przypadająca na mieszkańca gminy wynosiła 1721 zł w 2020 r., przy czym w gminach wiejskich ich średnia na mieszkańca była najwyższa, tj. 1843 zł, w gminach miejsko-wiejskich wynosiła 1737 zł, a w gminach miejskich - tylko 1583 zł. Najniższą wartość środkową odnotowano w grupie gmin miejskich - tj. 1583 zł, w gminach miejsko-wiejskich - 1745 zł, w wiejskich były to najwyższe kwoty - 1829 zł. Minimalne dotacje per capita otrzymane przez poszczególne rodzaje gmin były zbliżone i mieściły się w przedziale od 1120 zł (gminy miejskie) do 1176 zł (gminy wiejskie). Większe dysproporcje pojawiły się w przypadku maksymalnych kwot dotacji w przeliczeniu na mieszkańca. W grupie gmin wiejskich było to aż 3037 zł, w miejsko-wiejskich - 2478 zł, natomiast w wiejskich - 2264 zł. Najmniejsze odchylenia w stosunku do wartości średniej w grupie występowały w gminach wiejskich - 194 zł, mniejsze były w gminach miejsko-wiejskich - 209 zł, a największe w gminach wiejskich - 237 zł.

\section{Podsumowanie}

Przeprowadzone analizy i badania pozwalają stwierdzić, że Polska należy do państw, w których transfery z budżetu państwa odgrywają dużą rolę w finansowaniu JST. Korzystne jest to, że duża część środków przekazywanych z budżetu państwa ma ogólne przeznaczenie i nie ogranicza samodzielności wydatkowej JST, jednocześnie jest też dla nich pewnym dochodem. Niekorzystne natomiast jest to, że w latach 2010-2020 wskaźnik ingerencji finansowej państwa zwiększył się w gminach i miastach na prawach powiatu. Na koniec okresu badawczego w gminach i powiatach przekraczał on 51\%, w miastach na prawach powiatu wyniósł prawie 39\%, a w województwach - 19\%. Największy udział w dochodach ogółem subwencja ogólna ma w powiatach, co wynika z jednej strony z szerokiego zakresu wykonywanych przez nie zadań oświatowych, a z drugiej - ze słabości finansowej tych jednostek, spowodowanej stosunkowo niskimi dochodami własnymi. Województwa, jako podmioty niezaangażowane w większym stopniu w wykonywanie zadań edukacyjnych, cechuje dość niski wskaźnik subwencji w dochodach ogółem.

Przyjęty w Polsce system subwencjonowania opiera się na środkach pochodzących z budżetu państwa, zatem przeważa w nim wyrównywanie pionowe, a udział środków transferowanych w mechanizmie redystrybucji poziomej stanowi jedynie 3,9\% subwencji ogólnej. Kryteria przy- 
znawania transferów ogólnych uwzględniają głównie aspekt kosztowy realizacji zadań (część oświatowa, kwota uzupełniająca subwencji wyrównawczej dla gmin i powiatów, 75\% części równoważącej dla gmin, 76\% - dla powiatów oraz 52\% części regionalnej). Wyrównywaniu dysproporcji dochodowych służą natomiast głównie kwoty podstawowe subwencji wyrównawczej oraz częściowo (ale w mniejszym stopniu niż wyrównywaniu kosztów) subwencje równoważąca i regionalna. Rezerwa subwencji ogólnej również jest rozdysponowywana z uwzględnieniem realizowanych zadań, a w konsekwencji brane są pod uwagę koszty obciążające JST. Przyjęte w Polsce mechanizmy wyrównywania dochodów nie demotywują władz samorządowych ani nie zniechęcają ich do zabiegania o dodatkowe źródła finansowania jednostki, nigdy bowiem nie wypełniają luki między jej dochodami a średnimi dochodami uzyskiwanymi przez jednostki danego szczebla w państwie.

Dotacje celowe, jeśli nie brać pod uwagę środków przekazywanych w ramach programów realizowanych z udziałem funduszy europejskich, charakteryzują się bardzo zmiennym poziomem i dużym zróżnicowaniem pomiędzy poszczególnymi JST. Służą one głównie pokrywaniu wydatków ponoszonych przez JST na skutek realizacji zadań zleconych ustawami i przez organy administracji rządowej. Dofinansowanie, jakie gminy, powiaty i województwa otrzymują na zadania własne, jest stosunkowo niskie. Przeważnie dotacje celowe przekazywane są na zadania bieżące, a tylko niewielka ich część ma charakter inwestycyjny. Zasadniczo służą redystrybucji i przekazywane są jako wsparcie dla rodzin oraz pomoc społeczna. Przy ustalaniu wysokości dotacji abstrahuje się od zamożności jej beneficjenta, główne znaczenie ma cel, na jaki jest ona przyznawana, a którego osiągnięcie łączy się z koniecznością poniesienia określonych wydatków.

\section{Bibliografia}

Boadway R., Shah A., Fiscal Federalism. Principles and Practice of Multiorder Governance, Cambridge University Press, New York-London 2009.

Borodo A., Samorzad terytorialny. System prawnofinansowy, LexisNexis, Warszawa 2004.

Carroll D.A., Johnson T., Examining Small Town Revenues: To What Extent Are They Diversified? „P Public Administration Review" 2010, t. 70, nr 2, https://doi.org/10.1111/j.1540-6210.2010.02129.x.

Dziemianowicz R., Dysfunkcje udziałów w podatkach państwowych w aspekcie zmniejszajqcej się samodzielności dochodowej samorzqdu terytorialnego w Polsce, "Prace Naukowe Uniwersytetu Ekonomicznego we Wrocławiu” 2017, nr 485, https://doi.org/10.15611/pn.2017.485.08.

Guziejewska B., Subwencje i dotacje dla samorzqdu terytorialnego w polityce finansowej państwa, "Gospodarka Narodowa" 2007, nr 4, https://doi.org/10.33119/gn/101396.

Guziejewska B., Zewnętrzne źródła finansowania samorządu terytorialnego, Wydawnictwo Uniwersytetu Łódzkiego, Łódź 2007.

Kańduła S., Dyskusja na temat zasadności poziomej redystrybucji dochodów między jednostkami samorzqdu terytorialnego, "Studia Regionalne i Lokalne” 2015, nr 3(61).

Kańduła S., Mechanizmy wyrównywania fiskalnego. Studium empiryczne gmin w Polsce w latach 2004-2014, Wydawnictwo Uniwersytetu Ekonomicznego w Poznaniu, Poznań 2017. 
Lachiewicz W., System prawa dotacyjnego [w:] Dotacje z budżetów jednostek samorządu terytorialnego, red. W. Lachiewicz, A. Talik, C.H. Beck, Warszawa 2017.

Malinowska-Misiąg E., Misiąg W., Finanse publiczne w Polsce, LexisNexis, Warszawa 2007.

McGovern M., Kay A., Bristow G., Pickernell D., Turkeys Don't Vote for Christmas? An Analysis of Horizontal Fiscal Equalisation Experiences in Australia and the United Kingdom, „Economic Papers. Journal of Applied Economics and Policy" 2002, t. 21, nr 4, https://doi.org/10.1111/j.1759-3441.2002.tb00330.x.

Miszczuk A., Miszczuk M., Żuk K., Gospodarka samorzq̨du terytorialnego, Wydawnictwo Naukowe PWN, Warszawa 2007.

Oates W.E., An Essay on Fiscal Federalism, „Journal of Economic Literature” 1999, t. 37, nr 3.

Ofiarski Z., Subwencja jako forma prawna wydatków dokonywanych z budżetu państwa, „Ruch Prawniczy, Ekonomiczny i Socjologiczny" 2011, z. 3.

Owsiak K., Kontrowersje wokół dotacji celowych dla jednostek samorzq̨du terytorialnego, „Prace Naukowe Uniwersytetu Ekonomicznego we Wrocławiu" 2017, nr 485, https://doi.org/10.15611/pn.2017.485.27.

Papcunová V., Hudáková J., Štubnová M., Urbaníková M., Revenues of Municipalities as a Tool of Local Self-Government Development (Comparative Study), „Administrative Sciences” 2020, t. 10, nr 4, https://doi.org/10.3390/ admsci10040101.

Patrzałek L., Dotacje jako transfery z budżetu państwa i budżetu jednostki samorzqdu terytorialnego, „Annales Universitatis Mariae Curie-Skłodowska. Sectio H. Oeconomia" 2017, t. 51, nr 6, https://doi. org/10.17951/h.2017.51.6.293.

Patrzałek L., Finanse samorzadu terytorialnego, Wydawnictwo Uniwersytetu Ekonomicznego we Wrocławiu, Wrocław 2010.

Patrzałek L., Subwencja ogólna jako instrument korekcyjno-wyrównawczy w systemie finansów samorzqdu terytorialnego, „Prace Naukowe Uniwersytetu Ekonomicznego we Wrocławiu” 2015, nr 404, https://doi.org/10.15611/ pn.2015.404.16.

Rosen F.S., Public Finance, McGraw-Hill, 2014.

Sekuła A., Stosowanie mechanizmu wyrównania poziomego w województwach - skutki dla dochodów budżetów, „Prace Naukowe Uniwersytetu Ekonomicznego we Wrocławiu” 2018, nr 528, https://doi.org/10.15611/ pn.2018.528.17.

Sekuła A., System subwencjonowania samorządu terytorialnego w Polsce i pożądane kierunki racjonalizacji, Politechnika Gdańska, Gdańsk 2016.

Shah A., The Reform of Intergovernmental Fiscal Relations in Developing and Emerging Market Economies, World Bank, Washington 1994.

Surówka K., Winiarz M., Kierunki zmian ustawy o dochodach jednostek samorzqdu terytorialnego, Małopolska Szkoła Administracji Publicznej, Kraków 2014, https://www.nist.gov.pl/files/zalacznik/1452372345_K. Sur\%C3\%B3wka\%20-\%20Ustawa\%200\%20dochodach\%20JST.pdf.

Swianiewicz P., Transfery z budżetu państwa dla samorządów lokalnych, „Studia Regionalne i Lokalne” 2003, nr 1(11).

Szołno-Koguc J., Subwencja ogólna jako instrument wsparcia transferowego samorządu gminnego, „Prace Naukowe Uniwersytetu Ekonomicznego we Wrocławiu" 2017, nr 485.

Uryszek T., Dochody transferowe jednostek samorzqdu terytorialnego a ich samodzielność wydatkowa „ „Ekonomiczne Problemy Usług" 2011, nr 76. 


\section{Akty prawne}

Europejska Karta Samorządu Lokalnego, sporządzona w Strasburgu dnia 15 października 1985 r. (Dz.U. 1994, nr 124, poz. 607; z uwzględnieniem Dz.U. 2006, nr 154, poz. 1107).

Rozporządzenie Ministra Edukacji i Nauki z dnia 18 grudnia 2020 r. w sprawie sposobu podziału części oświatowej subwencji ogólnej dla jednostek samorządu terytorialnego w roku 2021 (Dz.U. 2020, poz. 2384).

Ustawa z dnia 2 października 2003 r. o zmianie ustawy o specjalnych strefach ekonomicznych i niektórych ustaw (Dz.U. nr 188, poz. 1840, ze zm.).

Ustawa z dnia 13 listopada 2003 r. o dochodach jednostek samorządu terytorialnego (Dz.U. 2021, poz. 1672).

\section{Raporty}

OECD, European Commission, Key Data on Local and Regional Governments in the European Union, 2018, https:// www.oecd.org/regional/EU-Local-government-key-data.pdf.

Rada Ministrów, Sprawozdania z wykonania budżetu państwa za okres od 1 stycznia do 31 grudnia 2020 r. Informacja o wykonaniu budżetów jednostek samorzqdu terytorialnego, Warszawa 2021, https://www.gov.pl/web/finanse/ sprawozdanie-roczne-za-2020-rok.

Rada Ministrów, Sprawozdanie z wykonania budżetu państwa za okres od 1 stycznia do 31 grudnia 2020 r. Omówienie, Warszawa 2021, https://www.gov.pl/web/finanse/sprawozdanie-roczne-za-2020-rok.

UN-HABITAT, The Challenge of Local Government Financing in Developing Countries, Nairobi 2015, https://unhabitat.org/.

\section{Strony internetowe}

Bank Danych Lokalnych Głównego Urzędu Statystycznego, Finanse publiczne, https://bdl.stat.gov.pl/ BDL/dane/ podgrup/ temat.

Główny Urząd Statystyczny, https://stat.gov.pl/. 